\title{
Biotech Potatoes in the 21st Century: 20 Years Since the First Biotech Potato
}

\author{
Dennis Halterman ${ }^{1} \cdot$ Joe Guenthner $^{2} \cdot$ Susan Collinge $^{3}$. \\ Nathaniel Butler ${ }^{4}$ - David Douches ${ }^{4}$
}

Published online: 19 November 2015

(C) The Author(s) 2015. This article is published with open access at Springerlink.com

\begin{abstract}
Potato is the world's most important vegetable crop, with nearly 400 million tons produced worldwide every year, lending to stability in food supply and socioeconomic impact. In general, potato is an intensively managed crop, requiring irrigation, fertilization, and frequent pesticide applications in order to obtain the highest yields possible. Important traits are easy to find in wild relatives of potato, but their introduction using traditional breeding can take $15-20$ years. This is due to sexual incompatibility between some wild and cultivated species, a desire to remove undesirable wild species traits from adapted germplasm, and difficulty in identifying broadly applicable molecular markers. Fortunately, potato is amenable to propagation via tissue culture and it is relatively easy to introduce new traits using currently available biotech transformation techniques. For these reasons, potato is arguably the crop that can benefit most by modern biotechnology. The benefits of biotech potato, such as limited gene flow to conventionally grown crops and weedy relatives, the opportunity for significant productivity and nutritional quality gains, and reductions in production cost and environmental impact, have the potential to influence the marketability of newly developed varieties. In this review we will discuss current and past efforts to develop biotech potato varieties, traits that could be impacted,
\end{abstract}

Dennis Halterman

dennis.halterman@ars.usda.gov

1 Vegetable Crops Research Unit, U.S. Department of Agriculture, Agricultural Research Service, Madison, WI 53706, USA

2 Department of AERS, University of Idaho, Moscow, ID 83844-2334, USA

3 Plant Sciences, J.R. Simplot Company, Boise, ID 83706, USA

4 Department of Plant, Soil, and Microbial Sciences, Michigan State University, East Lansing, MI 48824, USA and the potential effects that biotech potato could have on the industry.

Resumen La papa es el cultivo hortícola más importante en el mundo, con cerca de 400 millones de toneladas producidas a nivel mundial anualmente, acreditando la estabilidad en el suministro de alimentos e impacto socioeconómico. En general, la papa es un cultivo manejado intensivamente, que requiere riego, fertilización y aplicaciones frecuentes de plaguicidas para obtener los más altos rendimientos posibles. Los caracteres importantes son fáciles de encontrar en parientes silvestres de la papa, pero su introducción usando el mejoramiento tradicional puede llevar de 15 a 20 años. Esto es debido a la incompatibilidad sexual entre algunas especies silvestres y cultivadas, el deseo para eliminar características indeseables de las especies silvestres del germoplasma adaptado, y la dificultad en la identificación de marcadores moleculares aplicables ampliamente. Afortunadamente, la papa es receptiva a la propagación por cultivo de tejidos y es relativamente fácil la introducción de nuevos caracteres usando técnicas biotecnológicas de transformación actualmente disponibles. Por estas razones, la papa es probablemente el cultivo que se puede beneficiar mayormente por la biotecnología moderna. Los beneficios de la papa biotecnológica, como el flujo genético limitado a cultivos que se siembran convencionalmente y a los parientes como malezas, la oportunidad para productividad significativa y logros en calidad nutricional, y las reducciones en los costos de producción e impacto ambiental, tienen el potencial para influenciar la comercialización de las más nuevas variedades desarrolladas. En esta revisión discutiremos los esfuerzos actuales y pasados para desarrollar variedades biotecnológicas de papa, rasgos que pudieran impactarse, y los efectos potenciales que la papa biotecnológica pudiera tener en la industria. 
Keywords Potato $\cdot$ Genetic modification $\cdot$ Stress resistance traits $\cdot$ Tuber quality traits

\section{Introduction}

Since the introduction of the first genetically modified (GM)/ biotech crop plants in the mid-1990s, the agriculture industry has seen a steady increase in the acreage of those crops planted and harvested worldwide each year. In 2014, a record 18 million farmers in 28 countries planted 447 million acres of biotech soybean, maize, cotton, canola, zucchini squash, papaya, alfalfa, poplar, sugar beet, tomato, eggplant, and sweet pepper (James 2014). This represents a more than 100-fold increase in usage between 1996 and 2014. This increase is largely due to the economic, environmental, and productivity benefits derived from their use.

The vast majority of biotech crops grown worldwide continue to be used primarily for animal feed (soybean, maize, alfalfa) or for fiber products that are not directly consumable (cotton), although many of the foods we eat contain ingredients derived from biotech crops (e.g., oils, starches, sugars). The appearance of direct-to-consumer biotech crops on the market is increasing as biotech sweet corn, wheat, apple, papaya, and potato have already completed or are currently awaiting the completion of the regulatory clearance process. The generation of new biotech crops has been hindered primarily by costs associated with their development and regulatory clearances. Estimates place the cost of bringing a new biotech crop to market at around $\$ 136$ million, with the largest cost associated with trait discovery (McDougall 2011). The costs associated with the development of a new biotech crop variety make it difficult for research scientists to carry out the entire process without industry and market support (Miller and Bradford 2010). However, in some cases where a devastating disease threatens crops, we have seen the relatively rapid release and acceptance of biotech crops containing resistance, such as with virus resistant Rainbow papaya (Gonsalves 1998).

In the U.S., potato annually accounts for $\$ 4.2$ billion in production value and the crop is grown on just over a million acres (NASS 2015). Potato is an ideal crop for the introduction of traits using biotechnology. In fact, after virus-resistant tobacco (China in 1992) and the FlavrSavr tomato (U.S. in 1994), potato was one of the first crops to be genetically modified; it was grown commercially as NewLeaf ${ }^{\mathrm{TM}}$ by Monsanto in 1995. Conventional potato breeding as it is practiced worldwide is an inefficient, slow process that has changed little in the past century. Potato requires considerable inputs of nutrients, pesticides, and water to maintain yield, quality, and protection from diseases and insects. Potato breeding efforts have historically focused on yield, fresh market and processing quality, and storability as well as disease resistance. Genetic variation for these traits in commercial cultivars is low, but related wild species contain many traits not found in cultivars and represent an especially rich source of disease resistance and tuber quality genes (Hanneman 1989; Jansky 2000). Efforts have been made to introgress nutritional qualities and resistance to pests and abiotic stresses from wild species into cultivated potato, but popular cultivars have few traits derived from wild germplasm due to their genetic complexity, unpredictable expression in adapted backgrounds, and a desire by industry to limit variability in processing quality (Hirsch et al. 2013). In the U.S., the availability of effective pesticides, fungicides, fumigants, synthetic fertilizers, and irrigation systems has meant that market-driven traits, such as yield, are often given higher priority than biotic and abiotic stress resistances. Combining tuber quality traits desired by consumers and processors with the agronomic performance and disease resistance preferred by farmers remains the most significant challenge in potato breeding. Fortunately, the tremendous amount of genetic diversity in wild and cultivated relatives of potato allows for relatively easy identification, isolation, and introduction of new genes for a specific trait using biotechnology. For example, genes from wild potato relatives can contribute resistance to late blight, Verticillium wilt, potato virus $\mathrm{Y}$, water stress, and cold-induced sweetening (see following discussion). The fact that genes of interest can be derived from wild relatives of potato allows for the production of biotech varieties by inserting potato DNA. This is contrasted with traditional transgenic plants that use DNA derived from bacteria, viruses, or other organisms.

In addition to the abundance of traits available for potato improvement, potato can be propagated easily in tissue culture, making it straightforward to integrate specific genes and recover plants from transformed tissue (Chakravarty et al. 2007). Some cultivars are more amenable to tissue culture than others, but with appropriate protocol modifications, most are capable of undergoing transformation using Agrobacterium tumefaciens and regeneration of plant tissue. The use of Agrobacterium to introduce genes of interest is the most common method of stable transformation in potato, although other methods such as particle bombardment, protoplast transformation, and microinjection have been successful. Regardless of the method, these approaches require regulatory clearance of the resulting potato variety before wide-scale release and production. Regulatory clearance in the U.S. can involve up to three federal agencies: the Environmental Protection Agency (EPA), the Food and Drug Administration (FDA), and the US Department of Agriculture (USDA). Relatively new methods to specifically edit regions of the plant genomes are also being developed and may provide a method for genetic improvement that fits outside the traditional regulatory process (Waltz 2012). Companies specializing in gene editing, such as Calyxt (formerly Cellectis Plant Sciences), are using these new tools to 
modify specific traits in tetraploid potato (Clasen et al. 2015).

The biotech potatoes commercialized in the mid-1990s (Toevs et al. 2011b) were a technological success and provided benefits to producers, consumers, and the environment, but anti-GMO pressure regarding the safety of biotech food crops led to their removal from the market in 2002, and their status remained unchanged for more than a decade. With the widespread approval and adoption of other biotech crops, there is a renewed interest in the development of biotech potato which has led to the arrival of biotech potatoes back on the market in 2015.

The purpose of this review is to provide readers with an overview of biotech potato including its history, past and potential impact on the industry, targeted traits, consumer perception, and biotech crop safety. Genetic modification of potato to introduce agronomic-, production-, and consumeroriented traits has led to an opportunity to revolutionize potato breeding and offer an alternative to traditional variety selection methods. We are hopeful that market acceptance of the technology will increase efforts towards the discovery of genes that could be used to improve current varieties. The use of biotechnology will provide a much-needed avenue for the introduction of unique traits present in wild potato relatives, which would typically be difficult or impossible to introduce into cultivated potato using traditional methods.

\section{History of Biotech Potato}

In 1995 Monsanto released the first biotech potato used in agricultural production, the Russet Burbank variety containing the CryIIIA gene to provide resistance to Colorado Potato Beetle (CPB; USDA-APHIS 2015). Named NewLeaf ${ }^{\mathrm{TM}}$, this marked the introduction of the company's first biotech crop of any type. NatureMark, a wholly-owned subsidiary of Monsanto, eventually marketed three varieties of CPBresistant potato - Atlantic, Russet Burbank, and Superior and branded them with the NewLeaf ${ }^{\mathrm{TM}}$ trademark. In regions where CPB was a problem, NewLeaf ${ }^{\mathrm{TM}}$ potatoes quickly became popular among growers. The product was very effective at preventing CPB damage and U.S. plantings of NatureMark potatoes expanded rapidly, from 1,800 acres in 1995 to 55,000 acres in 1998. Three years after rolling out its biotech potatoes, NatureMark varieties comprised four percent of the U.S. crop. By 1991, Monsanto had developed potatoes resistant to both CPB and potato leafroll virus (PLRV) (Perlak et al. 1993; Kaniewski and Thomas 2004). In 1998, NatureMark introduced NewLeaf Plus ${ }^{\mathrm{TM}}$, a Russet Burbank variety with resistance to both CPB and PLRV.

Other NatureMark products in development at that time included resistance to late blight and tubers with increased specific gravity (Kaniewski and Thomas 2004). Not surprisingly, Monsanto was not the only organization investing in biotech potatoes. Scientists with other firms and universities around the world were conducting research and field testing biotech potatoes. Much of the effort went into pest resistance, especially late blight resistance, but processing traits were also targets.

Anti-GMO activism fueling public debate regarding the safety of biotech crops eventually led to problems with marketing NewLeaf ${ }^{\mathrm{TM}}$ potatoes used for processing. The food industry, consumer groups, and anti-biotech activists, who remained quiet at first, began voicing opposition to products derived from biotech potato. Quick service restaurants reacted by moving away from frozen fries made with biotech potatoes. Fueling the debate surrounding biotech potato products, one frozen potato processor tried to differentiate its fries by guaranteeing that they were GM-free (Guenthner 2001). The North American fresh market continued to accept biotech potatoes, but with processed potato markets closing, growers became reluctant to take on the risk of planting biotech potatoes. Surrendering to dwindling marketability for their products, Monsanto closed its NatureMark potato business in the Spring of 2001.

There were also problems with other processed potato markets. Raw product for dehydrated potato processing comes mostly from fresh packers who sort out potatoes that don't meet fresh quality standards. In the infancy of biotech crop commercialization, there was no perceived need for an identity preservation (IP) or directed marketing program for NewLeaf ${ }^{\mathrm{TM}}$ potatoes. There was general mixing of biotech and conventional potatoes within the dehydration supply chain (Toevs et al. 2011a). Although Monsanto had received Japanese government approvals for most NewLeaf ${ }^{\mathrm{TM}}$ potato varieties, when NewLeaf ${ }^{\mathrm{TM}}$ potatoes were withdrawn from the market, they were also withdrawn from domestic and international regulatory processes. After withdrawal, an unapproved event was found in dehydrated potatoes and the potato import tolerance level for that event was $0 \%$. The consequences of this action included rejected shipments and expensive product testing for the North American potato industry.

At about the time that Monsanto withdrew from the biotech potato business, the J.R. Simplot Company began efforts on product development, testing, and regulatory submissions. Learning from the marketing difficulties encountered by Monsanto, Simplot focused on consumer traits rather than producer traits for its first biotech potato products. Simplot also used only potato genes for trait introduction in order to address the public's concerns regarding biotech food safety.

One of the first consumer traits focused on by Simplot was potatoes that had a lower propensity for the formation of acrylamide, a substance linked to birth defects and cancer in mice and rats (National Toxicology Program 2011), and common in foods cooked at high temperatures. Anticipating the need for low-acrylamide raw product for its potato processing 
business, Simplot scientists successfully developed potatoes with a lower potential for producing acrylamide. A second consumer trait of interest to Simplot was black spot bruise resistance, which could reduce food waste during processing and open new avenues for marketing fresh cut potatoes.

In 2013 Simplot submitted a petition to the U.S. Department of Agriculture, Animal and Plant Health Inspection Service (USDA-APHIS 2015) seeking nonregulated status for its Innate ${ }^{\mathrm{TM}} 1.0$ potato with low acrylamide potential and black spot bruise resistance traits. In 2014, Simplot received deregulation from the USDA. This was followed by completing the food and feed safety consultation with the Food and Drug Administration (FDA) in 2015, opening the door for Simplot to commercialize Innate ${ }^{\mathrm{TM}} 1.0$ in Atlantic, Ranger Russet, and Russet Burbank potatoes.

In May 2015, the Innate ${ }^{\mathrm{TM}} 1.0$ potatoes entered the fresh and chip market channels as a limited commercial launch. Simplot implemented a directed marketing stewardship program to keep the biotech potatoes out of the dehydration and frozen processing market channels. The company also submitted a petition to USDA APHIS for Innate ${ }^{\mathrm{TM}} 2.0$ potatoes that have the same 1.0 traits but add late blight resistance and cold storage capability.

Efforts to develop and commercialize biotech potatoes continue around the globe, but outside North America only three varieties have received government approval as of May 2015 (ISAAA 2015). One is Amflora, a high-starch potato developed by BASF and approved in Europe, but no longer marketed. The other two, Elizaveta Plus and Lugovskoi Plus, are insect-resistant varieties developed by the Russian Academy of Sciences. Other biotech potato varieties have been developed, but have not completed regulatory clearances. In addition to Amflora, BASF also developed the varieties Modena, Amadea (both with increased amylopectin), and Fortuna (with late blight resistance). However, BASF halted its pursuit of regulatory approval of all biotech potato varieties in 2013 "because continued investment cannot be justified due to uncertainty in the regulatory environment and threats of field destructions" (BASF 2013).

The perseverance of biotech potato development and marketing should serve as a clear indication of the desire for improved potato varieties by growers and producers. Consumer acceptance of biotechnology is increasing and the coupling of new technologies with an increasingly scientifically literate public and a focus on consumer-oriented traits should favor widespread approval of biotech potato on the marketplace.

\section{Traits for Biotech Potato Development}

The integration of new traits into potato using biotechnology has some advantages and disadvantages compared to using traditional breeding to accomplish the same goal. Traditional breeding methods allow for crossing of two heterozygous tetraploid parents with widely different phenotypic assortments, with the expectation that a small percentage of the offspring will contain at least some of the desirable traits of both parents. Typically, progeny are then evaluated in the field to remove undesirable clones. This allows for the chance to introduce multiple desirable traits, especially when using parents that have contrasting appealing qualities. However, this process also allows for the incorporation of undesirable traits that must subsequently be selected against and, therefore, it can take a long time (1015 years) to produce a new marketable potato cultivar following the initial cross. The use of molecular markers associated with the desired traits can significantly speed up this process. New DNA sequencing technologies have facilitated the identification of thousands of potential markers for cultivated potato, but these markers must first be correlated with the selected trait (Hamilton et al. 2011) and then used to develop a laboratory-friendly (typically PCR based) method for their identification in segregating populations.

In contrast to traditional breeding, the time needed to introduce a specific gene into potato using Agrobacterium, followed by regeneration of the whole plant, is only 6-12 months. In addition, the targeted germplasm used for transformation can be an existing cultivar that already contains desirable agronomic characteristics and produces tubers with superior postharvest processing qualities. Stable integration of Agrobacterium transfer DNA inserts of up to around $150 \mathrm{ki}-$ lobases of DNA into a plant genome has been reported (Hamilton et al. 1996), which would allow for the introduction of multiple genes simultaneously. A disadvantage of using biotechnology for trait integration is that the gene(s) of interest must first be identified and cloned, which requires considerable expertise and effort. Genes that are expressed in a dominant fashion are of particular interest since backcrossing to achieve homozygosity is not required. However, gene silencing approaches allow for reduction in the expression of specific genes, resulting in a dominant negative effect (Pandey et al. 2015), eliminating the need to achieve homozygosity for traits that are normally inherited recessively, such as resistance to some diseases.

There are far too many published reports using biotech potato for gene characterization and trait incorporation to attempt to discuss all of them in this review. Therefore, this article focuses on traits that are currently being used to develop biotech potato lines or those that show potential to impact the marketability of biotech potato varieties in the future, with a particular interest on traits that can be addressed through the manipulation of gene expression or by using genes from potato and its close relatives. 


\section{Resistance to Biotic and Abiotic Stresses}

The introduction of pest resistance into cultivated varieties would reduce pesticide applications. Similarly, manipulation of gene expression that regulates water use efficiency in potato would allow for increased performance under water deficit conditions. Fortunately, collections of wild and cultivated potato germplasm are diverse and many wild species possess resistance to economically important diseases. Resistance to diseases is relatively easy to integrate because most traits are single genes that are inherited in a dominant fashion. Single genes can have a dramatic effect on the host when the pathogen is present, but rapid evolution of some pathogen genotypes has led to a breakdown of disease resistance after deployment. Our ability to use biotechnology to rapidly deploy stress resistance in popular cultivars and combine multiple genes for resistance offers certain advantages over traditional breeding.

Pattern Recognition Receptors Plants have a two-tiered defense system. The first layer of defense includes the recognition of certain pathogen byproducts (such as fungal chitin and bacterial flagellin or EFTu proteins) termed pathogen associated molecular patterns (PAMPs; reviewed by Zipfel 2014). PAMPs are recognized by receptor proteins located on the surface of the host cell. These pattern recognition receptors (PRRs) recognize the presence of PAMPs and activate defense responses. Interfamily transfer of PRRs has shown to produce resistance in the target plant and this increases the application potential of these genes in biotech crops. For example, the Brassicaceae-specific EFR protein, which recognizes bacterial $\mathrm{EFTu}$, can increase bacterial resistance in the Solanaceous plants tomato and Nicotiana benthamiana (Lacombe et al. 2010). Similarly, the Arabidopsis lectin receptor kinase LecRK1.9 is able to confer increased resistance to $P$. infestans when expressed in potato and $N$. benthamiana (Bouwmeester et al. 2014).

Although it is likely that many PRRs exist in potato, the only PRR that has been identified so far is the ELR protein, which recognizes the presence of the INF1 elicitin from P. infestans (Du et al. 2015). Other PRRs have been identified in closely related tomato and include EIX2 (recognizing fungal xylanase; Ron and Avni 2004), Ve1 (recognizing the Ave1 protein from Verticillium dahliae; Fradin et al. 2009), and Cf-9 (recognizing the AVR9 peptide from Cladosporium fulvum; Jones et al. 1994). Given the fact that PRRs are capable of interfamily transfer, it is likely that PRRs from within the Solanaceae family could increase disease resistance in potato. In fact, the tomato $\mathrm{Vel}$ gene when expressed in potato confers resistance to Verticillium dahliae (Kawchuk et al. 2001).

Disease Resistance Genes The second layer of plant defense relies on the function of resistance $(\mathrm{R})$ proteins that recognize specific pathogen molecules, termed effectors. The plant defense responses that are elicited by PRR and R proteins are similar, but $\mathrm{R}$ proteins typically elicit a stronger response, culminating in programmed cell death termed the hypersensitive response, which functions to limit spread of the pathogen. Pathogen effectors are highly diverse in function and molecular structure. In contrast, most $\mathrm{R}$ proteins share a similar overall structure and encode proteins with nucleotide binding (NB) and leucine-rich repeat (LRR) domains. For this reason, most plant $R$ protein candidates are immediately recognizable, which could potentially facilitate their identification once genomic locations responsible for resistance are known, or by using homology-based identification of candidate genes (Vossen et al. 2013).

The identification and cloning of several genes for resistance to the late blight pathogen Phytophthora infestans from wild relatives of cultivated potato has been published within the past 15 years. For example, $R 1, R 2$, and $R 3 a$ from Solanum demissum (Ballvora et al. 2002; Huang et al. 2005; Lokossou et al. 2009), Rpi-blb1, Rpi-blb2 and Rpiblb3 from S. bulbocastanum (Song et al. 2003; van der Vossen et al. 2003, 2005; Lokossou et al. 2009), Rpivnt1.1 from S. venturii (Foster et al. 2009; Pel et al. 2009), and Rpi-mcql gene from S. mochiquense (Jones et al. 2009) all provide resistance to individual or multiple strains of $P$. infestans (Fig. 1). The discovery of these genes has led to the identification of functionally equivalent variants derived from other wild potato species, such as $R B^{\text {ver }}$, Rpi-sto1, and Rpi-ptal from S. verrucosum, S. stoloniferum, and S. papita, respectively, which are related to Rpi-blb1 (Liu and Halterman 2006; Vleeshouwers et al. 2008). These additional genes provide supplementary genetic variation that could be used in the development of late blight resistant cultivars. In 2011, BASF petitioned for release of a biotech late blight resistant potato named Fortuna. Fortuna contains two resistance genes, Rpi-blbl $(R B)$ and Rpi-blb2. However, as mentioned previously Fortuna potato never made it to market. The second generation of Simplot's Innate ${ }^{\mathrm{TM}}$ potato will incorporate late blight resistance.

In addition to the numerous late blight $R$ genes isolated from wild potato relatives, several other $R$ genes have been cloned. The $R x 1$ and $R x 2$ genes from $S$. tuberosum ssp. andigena and $S$. acaule, respectively, confer resistance to potato virus X (Bendahmane et al. 1997, 2000), the Grol-4 gene from S. spegazzinii confers resistance to the root cyst nematode Globodera rostochiensis (Paal et al. 2004), and the Gpa2 gene from $S$. tuberosum ssp. andigena confers resistance to the pale cyst nematode $G$. pallida. Although potato $R$ genes have been identified for a only few diseases so far, this avenue of research remains a priority in many laboratories around the world. 
Fig. 1 Cultivar 'Superior' (left) and 'Superior' expressing the $R B$ (Rpi-blb1) gene 3 weeks after inoculation with the late blight pathogen Phytophthora infestans

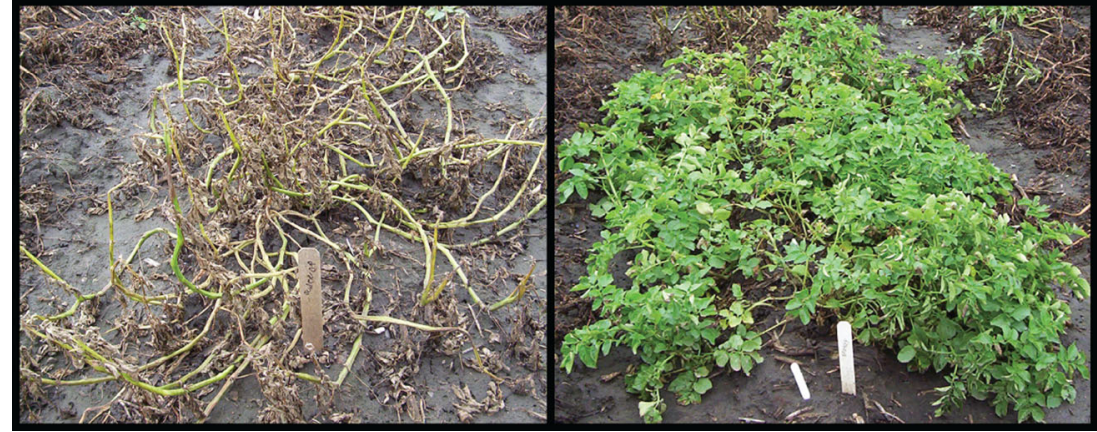

The NB-LRR class of disease $R$ genes is typically found within gene clusters that contain both functional and nonfunctional alleles (Michelmore and Meyers 1998), and susceptible hosts can also harbor nonfunctional $R$ genes with a high degree of sequence similarity to the functional variant. For these reasons, the development of molecular markers for $R$ genes that are both allele specific and broadly applicable across different genetic backgrounds has proven difficult. Therefore, the isolation of $R$ genes through map-based cloning and their introduction using stable transformation provides a rapid and reliable way to quickly introduce disease resistance into elite cultivars.

Other Genes Conferring Disease Resistance In addition to PRR and R proteins, other genes and mechanisms have the potential to be used to increase disease resistance in potato using biotechnology. One such example is the eIF4E gene that has been found to be associated with virus resistance in many plant species (Nicaise et al. 2003; Gao et al. 2004; Yoshii et al. 2004; Kang et al. 2005; Kanyuka et al. 2005; Stein et al. 2005; Nieto et al. 2006, 2007; Ibiza et al. 2010; Naderpour et al. 2010; Piron et al. 2010), including resistance to potato virus $\mathrm{Y}$ in potato, tomato, and pepper (Ruffel et al. 2002, 2005; Cavatorta et al. 2011; Duan et al. 2012). Variants of eIF4E confer resistance to PVY in the potato wild species relatives S. chacoense, S. demissum, and S. etuberosum (Duan et al. 2012), permitting the eventual use of this gene in future biotech potato varieties. Unlike PRR or R proteins, the eIF4E protein does not recognize the presence of a specific pathogen molecule to elicit resistance. Instead, it is a host protein required for proper translation of the viral genomic RNA. Mutations within $e I F 4 E$ render the protein unusable by the virus and therefore the virus is unable to replicate within the plant cell (Ruffel et al. 2002). In pepper and tomato, eIF4Emediated resistance is inherited in a recessive manner (Ruffel et al. 2002, 2005). However, introduction of the pepper gene into tomato or potato results in resistance that is dominant over the expression of the endogenous eIF4E variant (Kang et al. 2007; Cavatorta et al. 2011), demonstrating that deployment of eIF4E-based resistance from wild relatives into tetraploid potato is feasible without the need for removal or silencing of the endogenous susceptible allele. The mechanism by which the introduction of this eIF4E using biotechnology results in a switch from recessive to dominant resistance is not well understood and is currently a focus of multiple research projects.

It is well known that overexpression of virus genes in host plants can lead to increased resistance (reviewed by Goldbach et al. 2003). In papaya, transgenic plants expressing the coat protein from papaya ringspot virus led to increased resistance and saved the threatened Hawaiian papaya industry (Gonsalves et al. 2004). Scientists are now trying to use a similar approach to target other plant pathogens. Host induced gene silencing (HIGS) is a relatively new approach for controlling plant pathogens that relies on RNA interference to target the expression of essential pathogen genes. This strategy has been used to target a wide range of pathogen types including insects (reviews by Baum et al. 2007; Huvenne and Smagghe 2010), nematodes (reviewed by Huang et al. 2006; Yadav et al. 2006; Fairbairn et al. 2007; Sindhu et al. 2009), fungi (Nowara et al. 2010; Tinoco et al. 2010; Yin et al. 2011; Zhang et al. 2012; Koch et al. 2013; Panwar et al. 2013; Pliego et al. 2013; Ghag et al. 2014), parasitic weeds (Tomilov et al. 2008), and oomycetes (Govindarajulu et al. 2014; VegaArreguin et al. 2014; Jahan et al. 2015). Pathogen effectors essential for virulence or "housekeeping" genes necessary for normal pathogen growth are typically the targets for HIGS. The expression of gene fragments that result in the production of small interfering RNAs (siRNAs) are expressed in the host plant. The siRNAs subsequently move into the pathogen during infection to silence the target genes. In the only HIGS results using potato thus far, targeting of the $P$. infestans gene $h p-P i G P B 1$, which encodes a protein important in pathogenicity, resulted in reduced sporangia formation and disease progression in transgenic plants (Jahan et al. 2015). Not only does HIGS provide an experimental tool for determining the significance of specific genes in pathogen virulence, it also presents a new way to control plant diseases without having to identify and clone $R$ genes from the host. Additionally, by targeting genes that are essential for pathogen growth, rather than disposable effector targets, HIGS could provide more durable resistance, as it would be more difficult for these pathogen genes to be eliminated without impacting overall 
viability. Due to the fact that foreign gene fragments are being expressed in the host plant, it is likely that plants expressing HIGS constructs would need regulatory clearance prior to release.

Drought Resistance Most modern varieties of potato are considered drought susceptible (Mackerron and Jefferies 1988; Weisz et al. 1994; Yuan et al. 2003; Cabello et al. 2012; Monneveux et al. 2013) but variation does exist in landraces and wild relatives (Cabello et al. 2012). In Arabidopsis thaliana, manipulation of abscisic acid signal transduction through loss of function of the cap-binding protein 20 (CBP20) leads to increased drought tolerance (Papp et al. 2004). CBP20 interacts with the cap-binding protein 80 (CBP80) to form an active complex that is translocated to the nucleus (Kierzkowski et al. 2009). Silencing of CBP80 in potato cultivar Desiree led to a higher tolerance to drought (Pieczynski et al. 2013), indicating a promising target for future biotech potato varieties that require less water inputs.

\section{Tuber Quality Traits}

Lower Acrylamide Acrylamide, which is produced in starchrich foods processed under high temperatures, is a concern because it can cause cancer in laboratory animals at high doses, and is "reasonably anticipated to be a human carcinogen" (National Toxicology Program 2011). Potato chips and french fries provide a significant dietary contribution to acrylamide levels (Becalski et al. 2003). This has raised a worldwide food safety concern that has resulted in lawsuits against major potato and quick serve restaurant companies under California's Safe Drinking Water and Toxic Enforcement Act of 1986, also known as Proposition 65 (Office of Environmental Health Hazard Assessment 2015). Acrylamide was added to Proposition 65 in 1990, which requires businesses to warn Californians about the presence of chemicals that may cause cancer or reproductive toxicity in the products they purchase through labeling at restaurants or on product packaging. The substrates for the production of acrylamide are reducing sugars (glucose and fructose) and the amino acid asparagine. Consequently, one biotech strategy has focused on suppressing the accumulation of reducing sugars by down-regulating the production of the enzyme acid invertase, which cleaves sucrose into glucose and fructose (see below). This strategy has been very successful in transforming standard chip cultivars into clones with high levels of resistance to cold sweetening (Bhaskar et al. 2010; Ye et al. 2010). Another strategy to reduce acrylamide levels in processed potato products is to reduce expression of two genes required for asparagine synthesis (Chawla et al. 2012). The first generation of Simplot's Innate ${ }^{\mathrm{TM}}$ potato variety combines lower reducing sugar levels and decreased asparagine to address potential acrylamide issues (Simplot 2013).
Black Spot Bruise Resistance Tuber blackspot caused by impact and pressure during harvest and storage, as well as tuber tissue browning after cutting, is caused by the oxidation of phenolic compounds by the enzyme polyphenol oxidase (PPO) to quinones, which polymerize to cause dark pigmentation (Stevens and Davelaar 1997). Silencing of PPO genes in potato leads to a reduction in enzymatic browning of tuber tissue due to wounding and bruising from impact (Bachem et al. 1994; Coetzer et al. 2001; Chi et al. 2014). Innate ${ }^{\mathrm{TM}}$ potato will contain black spot bruise resistance through down-regulation of PPO (Fig. 2).

Cold Induced Sweetening Resistance Several tuber quality defects are caused by the accumulation of the reducing sugars glucose and fructose. These defects include cold-induced sweetening during storage at temperatures of less than $\sim 10^{\circ} \mathrm{C}$, sugar-end defect, and stem-end chip defect. At high temperatures, such as those reached during frying, reducing sugars react with amino acids in a non-enzymatic, Maillard reaction to produce dark-colored pigments (Benzing-Purdie et al. 1985). Chips and fries made from tubers with elevated reducing sugar contents are unacceptably dark in color and may have an undesirable bitter flavor. Silencing of the potato vacuolar acid invertase gene VInv prevents the accumulation of reducing sugar in tubers stored at cold temperatures (Fig. 3; Bhaskar et al. 2010). Similarly, overexpression of the vacuolar invertase inhibitor $I N H 2$ reduces acid invertase activity and the accumulation of reducing sugars in stored tubers (McKenzie et al. 2013).

Increased Amylopectin in Starch Conventional potato starch is composed of $80 \%$ amylopectin and $20 \%$ amylose. While the more prevalent amylopectin contains the properties needed by industry (adhesives, textiles, paper, construction materials, etc.), the presence of amylose in potato starch leads to problems in many technical applications. Therefore, potato starch requires pretreatment to modify amylose before it is suitable for industrial applications. The Amflora potato was developed by BASF, who petitioned for regulatory clearance in 1997. Thirteen years later, Amflora potato received

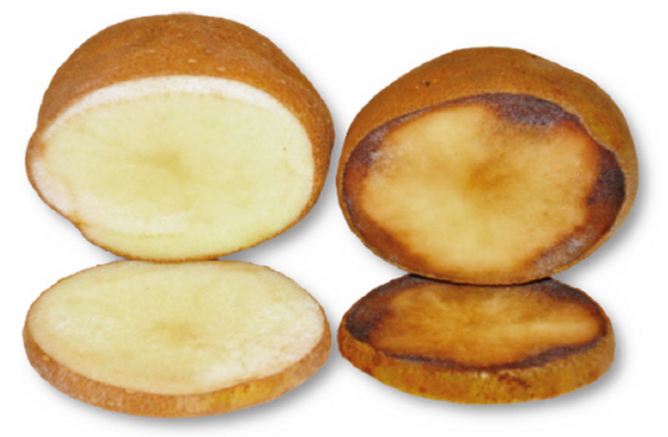

Fig. 2 Comparison of an Innate ${ }^{\mathrm{TM}}$ potato with a silenced polyphenol oxidase gene (left) and a traditional potato (right) $10 \mathrm{~h}$ after being cut 


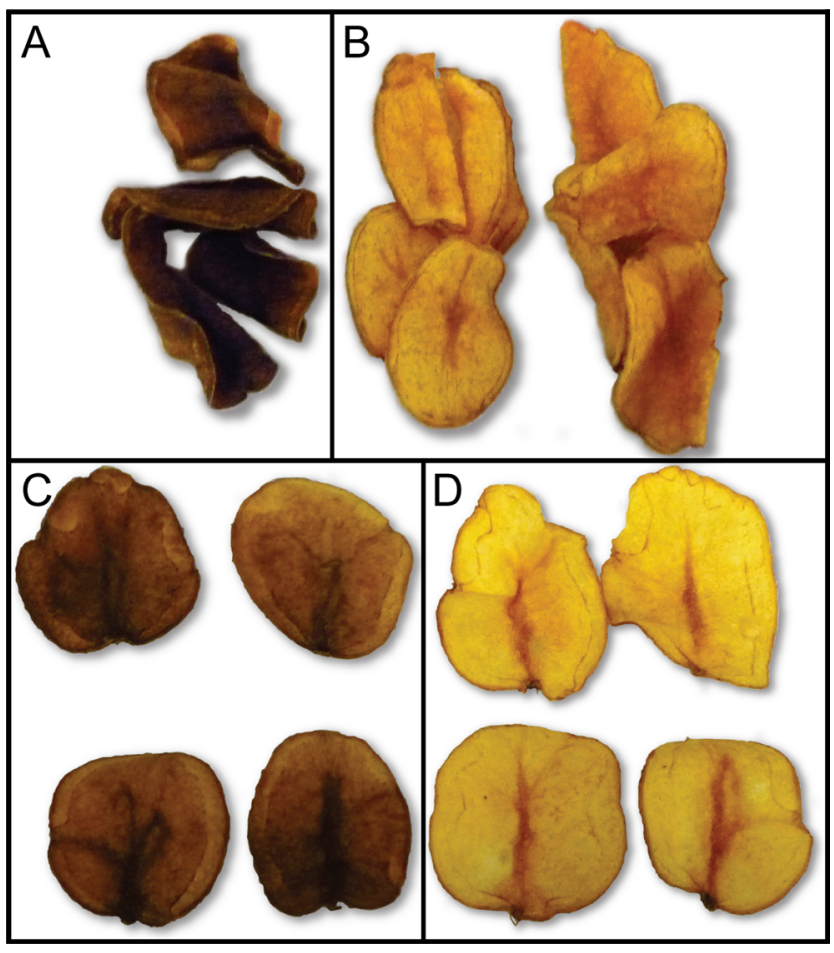

Fig. 3 Chips from tubers of wild-type Katahdin (a) and Katahdin with reduced expression of the vacuolar acid invertase gene (b) after being stored at $3{ }^{\circ} \mathrm{C}$ for 6 weeks. Chips made from tubers of wild-type MegaChip (c) and MegaChip with reduced expression of VInv (d) after storage at $3{ }^{\circ} \mathrm{C}$ for 16 weeks. Photos provided by Amy WiberleyBradford and Paul Bethke

European approval for commercial cultivation, which was the first genetically modified crop to receive EU approval since 1998. By silencing the granule bound starch synthase (GBSS) gene that controls amylose synthesis (Visser et al. 1991), Amflora potatoes contain only amylopectin. Another amylopectin potato variety, named Modena, was developed by the Dutch company AVEBE. In 2011, AVEBE passed ownership of Modena to BASF. A second generation of amylopectin potato, named Amadea, also was developed by BASF and was expected to eventually replace Amflora cultivation. However, as mentioned previously, BASF discontinued its pursuit of biotech potato regulatory clearance in 2013.

\section{Nutrition}

Vitamin C Our intake of ascorbate, or vitamin C, is primarily obtained through consumption of fruits and vegetables. While potato tubers contain ascorbate, they are a relatively poor source. A half cup $(61 \mathrm{~g})$ serving of baked potato provides only about $8 \mathrm{mg}$ of the recommended daily intake of 40-90 mg per day (USDA Nutrient Data Laboratory 2015). However, potato is capable of producing increased levels of ascorbate (Hemavathi et al. 2010; Bulley et al. 2012), leading to an opportunity to genetically enhance popular varieties to provide additional Vitamin $\mathrm{C}$ our diets.
Bulley et al. (2012) reported an up to threefold increase in ascorbate through the overexpression of a single potato gene, GDP-L-galactose phosphorylase.

Vitamin A Beta-carotene is the primary substate for synthesis of vitamin A in humans. Most potatoes are a poor source of beta-carotene, although some lines produce high levels of zeaxanthin, a xanthophyll that is derived from beta-carotene by the activity of the enzyme beta-carotene hydroxylase $(\mathrm{BCH}$; Brown et al. 1993). By silencing the $\mathrm{BCH}$ gene in potato using RNAi, Van Eck et al. (2007) were able to significantly increase beta-carotene content of tubers, even in lines that normally accumulate only low levels of zeaxanthin. Although the beta-carotene levels reached in these lines were lower than carotenoid-rich vegetables such as carrots or sweet potatoes, biofortification of potatoes offers an opportunity to provide added nutritional benefits to a food source that is already popular globally.

Glycoalkoloids Glycoalkaloids produced in potatoes (primarily $\alpha$-solanine and $\alpha$-chaconine) can contribute positively to potato flavor, but at higher levels contribute to bitterness and toxicity. Wounding and light exposure are known to affect glycoalkaloid content, which could lead to levels beyond the threshold of $20 \mathrm{mg}$ per $100 \mathrm{~g}$ fresh weight (Petersson et al. 2013), the level considered safe for human consumption (Smith et al. 1996). Many wild species of potato naturally produce high levels of glycoalkaloids (Gregory et al. 1981), leading to a need to monitor glycoalkaloid content when introducing other traits from these species. Therefore breeders must be mindful of glycoalkaloid levels when using wild species to develop germplasm. Silencing of the gene encoding a sterol alkaloid glycosyltransferase led to almost complete elimination of $\alpha$-solanine, with a correlated increase in $\alpha$ chaconine in some lines but not others (McCue et al. 2005).

\section{The Future of Trait Development and Incorporation Using Biotechnology}

As we continue to understand how biotic and abiotic stresses affect normal growth of crop plants such as potato, and identify the genes involved in resistance, opportunities to engineer new varieties using biotechnology will continue to arise. Many major genes for resistance to various diseases and abiotic stresses have already been mapped in potato germplasm and their cloning is inevitable. Using biotechnology to incorporate stress resistance genes provides certain advantages over conventional breeding. This includes 1) the relatively rapid development of new varieties once genes have been cloned. Plant pathogens can evolve quickly to overcome resistance and our ability to rapidly deploy novel genes is important to combat epidemics if they arise; 2 ) the ability to include multiple "modes of action", for example pyramiding PRR and R 
genes that recognize different molecules from the same pathogen, would make it more difficult for the pathogen to evolve to overcome resistance; 3 ) the addition of resistance from wild relatives without the incorporation of undesirable traits linked to the gene(s) of interest; and 4) an ability to quickly adapt existing varieties to new environments and markets that arise due to changing climates. Due to the fact that disease resistance proteins are considered biopesticides, biotech varieties with novel disease resistance genes fall under EPA authority. However, R proteins are clear examples of intractable proteins, as they are difficult or impossible to detect in plant tissue due to their low level of expression. Therefore, due to a very low level of exposure to $\mathrm{R}$ proteins and therefore low risk, safety assessments should consider these characteristics in similar disease resistant varieties (Bushey et al. 2014).

The genetic basis of complex agronomic traits such as flavor and texture, maturity, and yield is currently challenging to define in potato, as effective screens are difficult or many genes could be involved in the phenotypes. Quantitative traits such as these may be difficult to address using biotechnology, as the identification, isolation, and introduction of many genes, each with a minor contribution to the desired phenotype, would prove to be a difficult undertaking. However, as we continue to better understand the genes involved in complex traits and develop new tools for genetic modification, engineering varieties with desired complex traits should be achievable.

The future of biotech potato is reliant not only on traits important for improvement of the crop, but also on market acceptance, which is driven ultimately by consumers. While consumer oriented traits such as fortified nutrition, enhanced flavor, and superior appearance seem minor when considering the entire scope of potato production, we believe that it is these traits that will ultimately drive long-term acceptance of biotech potato. We are adopting the premise that using biotechnology to directly enhance our food in beneficial ways, rather than focusing solely on production oriented traits such as herbicide tolerance or disease resistance, will be favored by consumers and facilitate widespread market acceptance.

\section{Regulatory Clearances for New Biotech Products}

\section{Agencies Regulating Biotechnology in the U.S}

U.S. biotech regulatory responsibility falls within the USDA, FDA, and EPA under a program called The Coordinated Framework for Regulation of Biotechnology (Office of Science and Technology Policy 1986). The USDA evaluates biotech crops through the Biotechnology Regulatory Services (BRS) group within the Animal and Plant Health Inspection Service (APHIS). After a completed evaluation by the USDA, the biotech plants are no longer regulated and termed deregulated. The USDA BRS also regulates field trials of biotech crops and requires researchers to follow proper permitting and notification procedures. The FDA's authority for biotech crops falls under the Federal Food, Drug, and Cosmetic Act. FDA encourages a voluntary consultation process to ensure that food and feed meet all safety and labeling obligations before distribution. Although technically voluntary, all biotech foods currently on the market in the U.S. have completed the consultation process. In addition, EPA regulates plant incorporated protectants (PIPs) under the Federal Insecticide, Fungicide, and Rodenticide Act (FIFRA). In essence, such PIPs introduced through biotechnology are regulated as biopesticides. The EPA regulates both the pesticide and the genetic material necessary for its production. EPA also establishes an exemption from the requirement of a tolerance for residues of pesticides on and in food and animal feed under the Federal Food, Drug and Cosmetic Act. Regulatory clearance in the U.S. is necessary to allow for product sales, but also sets the stage for international approvals because some countries such as Mexico and China require full authorization in a major cultivation market prior to submission. In addition to regulatory authorizations, both USDA and EPA provide oversight and a review process before conducting field trials.

\section{USDA Petitions for Deregulation}

Petitions for deregulation with the USDA naturally will be focused on the authority of the agency under the Plant Protection Act, to evaluate the new bioengineered plant, such as the biotech potato, and determine it does not pose a plant pest risk. Information that is evaluated to support such a determination includes:

1) A rationale for the development of the biotech plant that includes benefits of the trait;

2) Background on the plant biology, often using international consensus documents such as those created by the Organization for Economic Co-operation and Development (OECD 1997);

3) Description of the transformation system including the donor genes;

4) Characterization of the genetic insert, including stability and validation of transfer of only the desired DNA sequence to confer the traits;

5) Quantification of expressed protein(s) related to the traits;

6) Agronomic performance;

7) Compositional assessment; and

8) Environmental Safety.

The evaluation of submissions by BRS results in a Plant Pest Risk Assessment and Environmental Assessment (EA). 
Both assessments are made publicly available for comments that are then considered by BRS before deregulation. This entire process is open for public review and also serves as informal guidance for future developers of biotech crops. If BRS concludes that the new variety does not meet the requirements for a "Finding of No Significant Impact (FONSI)" after conducting an EA, the agency may proceed with the more in depth process of completing an Environmental Impact Statement.

\section{FDA Consultation Process}

The voluntary review by FDA requires a submission much like that for USDA, except that the evaluation for food and feed safety does not require agronomic performance or an environmental assessment. Unlike the USDA, documents submitted to the FDA for this consultation are not readily available to the public, however, they can be obtained via the Freedom of Information Act. At the end of the review process, the FDA publishes a Biotechnology Agency Response Letter and a Consultation Note to the File on the FDA website (FDA 2015). For the compositional assessment, a comparison is made to determine if the biotech plant is not meaningfully different from the control. In its recent review of biotech potato, the FDA concluded in the Consultation Note to the File that Innate ${ }^{\mathrm{TM}}$ potatoes are not different in composition, safety, or any other relevant parameter from comparable potato varieties now grown, marketed, and consumed in the United States, except for the intended changes (FDA 2015). Unlike USDA and EPA, FDA has no specific requirements associated with releasing biotech crops into the environment prior to commercialization.

\section{EPA Regulatory Process}

EPA regulations for biotech crops have been adapted from guidelines that were written for microbial pesticides and applied them to Plant Incorporated Protectants (PIPs), the nomenclature for modern biotechnology traits that confer pesticidal or fungicidal activity, which include genes that confer resistance to microbes. Both USDA and EPA oversee field trials with biotech crops containing PIPs. Notifications with USDA are expected before any biotech crop is planted in field trials and crops containing PIPs must be registered with EPA before commercial sales. A submission for FIFRA registration includes the type of information expected for approval of a pesticide. This includes the product identity, toxicity, and a review of possible effects on humans, the environment, and non-target organisms. As with pesticides, EPA sets tolerances of maximum residue levels or exemption from the requirement of a tolerance for PIPs. All biotech crops registered with EPA have established tolerance exemptions based on safety assessments of the expressed proteins.

\section{Regulatory Challenges Specific for Potatoes}

Modifying potatoes through biotechnology has distinct advantages because of the extreme difficulty in breeding while maintaining the original desired characteristics. In crops like corn and soybean, a trait will be approved in one variety, and then crossed into many other varieties, but only the first transformation event requires regulatory approval. Typically, a biotech submission would be for a single event produced by inserting a gene into the genome of another plant. For example, a Bacillus thuringiensis (Bt) gene can be inserted into a corn variety and the event approved. Once approved for corn, this Bt gene can be backcrossed into many commercially important corn varieties without additional regulatory approvals.

The inability to backcross potatoes results in inefficiencies in the regulatory approval process. Because of the difficulty in breeding, a separate transformation is needed for each variety resulting in multiple separate approvals, one for each variety, even though they contain the same DNA construct. All regulatory requirements including field studies, molecular testing, and compositional analyses must be completed, leading to far more time, effort, and expense than for crops where backcrossing is feasible. This regulation by event results in far more approvals for the commercial use of biotech traits in multiple varieties of potatoes than in a crop like corn. There are more than 50 commercially important potato varieties (NPC 2014) that could potentially require separate transformations and approvals.

The petition for deregulation of the first generation of Innate ${ }^{\mathrm{TM}}$ potatoes contained multiple events, representing different potato varieties. Such multi-event submissions represent significant expense for the developers and potential to slow down the approval process within government regulatory departments. In anticipation of expecting repeated submissions of the same traits in multiple varieties of clonally propagated crops, both the U.S. and Canada have developed streamlined processes for approval of new events that result from a construct that has already been approved. The USDA has an extension process that allows for efficiencies in the submission requirements and a shorter expected evaluation time. In Canada, the biotech regulations are driven by consideration that insertion of a trait results in a novel food. Once a trait has been approved, it would not be considered novel. It would be expected that the Canadian Food Inspection Agency would have reduced requirements for new varieties transformed with the same traits. Health Canada still anticipates receiving a full safety package for the new varieties.

\section{The Future of Biotech Potato Regulatory Clearances}

The challenges of breeding potatoes while maintaining desired characteristics make the use of biotechnology ideal to take advantage of traits currently available to enhance quality 
and disease resistance. A major difficulty with obtaining approvals appears to be the need for replicating the requirements in multiple potato varieties because potatoes lack the ability to backcross. As regulatory groups become accustomed to clonal crops, it is anticipated that other countries will streamline processes as is occurring in the U.S. and Canada. Ideally, more governments will accept submissions with multiple events and streamlined evaluation when identical constructs and traits are presented in multiple potato varieties.

\section{New Tools for Genetic Improvement of Potato}

In the past several years, new methods have been developed for the targeted modification of plant genomes. These methods enable precise alterations of plant DNA in vivo, ranging from the introduction of single nucleotide substitutions (Townsend et al. 2009) to the targeted insertion of transgenes (Shukla et al. 2009). These new methods are quickly changing the way plant genetic engineering is being conducted and will likely affect how biotech crops are regulated by government agencies and perceived by the public. For example, why insert a foreign gene from a bacterium to confer herbicide resistance when subtle alterations to native plant genes can generate the same phenotype? Why integrate transgenes randomly when they can now be delivered to a specific locus where expression patterns are predictable?

Precise genome modification, or genome editing, is enabled by sequence-specific nucleases that create targeted chromosome breaks, enabling the cell's DNA repair pathways to be harnessed to introduce desired sequence modifications at or near the break site. Currently available sequence-specific nucleases include zinc finger nucleases (ZFNs), homing endonucleases or meganucleases, transcription activator-like effector nucleases (TALENs) and CRISPR/Cas (Puchta and Fauser 2014). In eukaryotes, the fate of a double-strand break follows one of two pathways. In most cases, the broken chromosome is simply rejoined, often integrating or deleting short segments of DNA at the break site and potentially knocking out gene function as part of non-homologous end-joining. In more rare cases, homologous recombination (HR) is employed where a homologous repair template or donor molecule is used to repair the broken chromosome. The donor molecule can include modified or additional sequence ranging from a few base pairs to entire genes. In higher eukaryotes, such as plants, this process is reliant on a nuclease-mediated double-strand break and abundance of donor molecule for efficient HR to occur (Puchta et al. 1996; Wright et al. 2005).

Genome editing tools provide a potential alternative to traditional Agrobacterium-mediated introduction of a gene of interest. By precisely editing plant genomic DNA or targeting the specific expression of certain genes without introducing any permanent foreign DNA, genome editing could address issues associated with traditional transgenics that require new events to go through the deregulation process. TALENs have proven their utility as reagents for genome editing in plants; however, the TALE DNA binding domain is derived from the bacterial plant pathogen Xanthomonas and may trigger a regulated status as codifed by USDA/APHIS regulation 7 CFR part 340 if integrated within transgenic events being developed for commercial use.

The biotech company, Calyxt has avoided the complication of integrating genome editing reagents by employing a transient transformation system using protoplasts to deliver TALENs that targeted all four homologs of the potato vacuolar invertase gene (VInv). Events regenerated from protoplasts contained one to four mutated alleles that negatively correlated with reducing sugar and acrylamide content following cold storage in the commercial variety, Ranger Russet (Clasen et al. 2015). Among these events, $39 \%$ were negative for the TALEN transgene and have been given non-regulated status under the USDA as null segregates (http://www.aphis.usda. gov/). Transient expression and use of null segregants provides an attractive approach for utilizing genome editing reagents to fast-track development of commercial biotech events (Haun et al. 2014; Clasen et al. 2015).

In addition to permanent editing of the potato genome through the use of ZFNs, TALENs, or CRISPR/Cas, other tools for gene expression modification are just beginning to be explored. Plant microRNAs (miRNAs) are short (20-24 nucleotides), non-coding RNA molecules important in posttranscriptional regulation of gene expression. Hundreds of endogenous plant miRNAs have been identified and can have wide-ranging effects on plant development, abiotic and biotic stress responses, protein turnover, and signaling through the regulation of specific genes, many of which are transcription factors (reviews by Zhang et al. 2006; Ruiz-Ferrer and Voinnet 2009). In potato, hundreds of miRNAs have been identified (Zhang et al. 2009, 2013; Yang et al. 2010; Kim et al. 2011; Xie et al. 2011). While the targets of potato miRNAs are relatively easy to ascertain through sequence homology, the effect that miRNA expression has on potato metabolism and development is only beginning to be explored. MicroRNAs require perfect or near-perfect complementarity to target genes, and are therefore quite target specific. This presents an opportunity in the future to use certain miRNAs, such as those involved in tuber development or biotic stress responses, to modify important traits, such as increased yield or disease resistance.

Application of genome editing technology, such as that available through CRISPR/Cas and TALENs, and manipulation of gene expression through miRNA targeting would be a paradigm for potato breeding and improvement efforts. Not only would social, regulatory, and market issues be addressed through the use of these advanced technologies (Simon 2003), but more consistent gene expression of target genes may also 
be achieved, thereby reducing the effort required to identify high-performing biotech lines (Duan et al. 2014). Furthermore, the use of transient expression methods to deliver genome editing reagents allows modification of established varieties without the need for further breeding and potentially forgoes the need for regulatory clearance before commercial release. This opens the door for the development of new potato varieties developed using CRISPR/Cas or TALENs that could be ready for field testing within the next few years, followed by marketability within the next $8-10$ years.

\section{Agronomic Effects of Biotech Potato}

Following the creation of new biotech potato cultivars, two possible agronomic issues should be considered. The first is the potential for pollen flow from the modified cultivars to either weedy relatives or conventionally grown potato cultivars after their release into the field. Several Solanum relatives of potato can be found as weeds in potato growing regions of the U.S. and Canada. These include hairy nightshade (S. physalifolium), bittersweet nightshade (S. dulcamara), and black nightshade (S. nigrum). However, studies have shown that these species are not sexually compatible with cultivated potato (Eijlander and Stiekema 1994; McPartlan and Dale 1994) and therefore the movement of biotech traits from potato into related weeds is not likely to occur. The same is true for the incompatibility between potato and other Solanaceous crops, such as tomato, eggplant, and pepper. Some wild species of potato are sexually compatible with cultivated varieties, which could pose problems for biotech potato grown in areas were wild species are prevalent (Scurrah et al. 2008). In the U.S., populations of wild potato exist in the Southwest (Hijmans and Spooner 2001) and have been identified in potato growing regions, but the risk of successful hybridization is very low (Love 1994), as there are no reports of this happening even in intentional cross-pollination experiments (J. Bamberg, pers. communication). Multiple reports have demonstrated that movement of potato pollen over $20 \mathrm{~m}$ is very unlikely (Tynan et al. 1990; Dale 1992; McPartlan and Dale 1994; Conner and Dale 1996), which suggests that the risk of pollen movement from a field containing biotech potato to conventionally grown potatoes in an adjacent field is minimal. Additionally, unlike many grain and legume crops, the product of pollination in potato is not harvested and is not used for propagation of a new crop. Volunteer potato plants, if present, are typically eliminated in subsequent field plantings through the use of selective herbicides. Consequently, with current farming practices it is highly unlikely for introduced genes to be passed from biotech potato cultivars to conventional ones.

A second possible consideration arises when biotech crops contain modifications that alter the structure of the genome in an unpredictable way. Some worry that these modifications could have unforeseen consequences. However, if the gene being introduced originates from a wild potato relative, then the amount of genetic modification is actually no more than if traditional breeding were used to introduce the gene. The biotech plant will contain only the segment of DNA inserted during transformation, while a plant developed by breeding is expected to follow normal Mendelian genetics and contain $50 \%$ exotic germplasm after the first cross, $25 \%$ after the first backcross, and so on. Finally, some biotech edited plants would be created by knocking out the function of existing genes, so they do not rely on the introduction of new genes. All biotech traits are extensively tested in field and greenhouse trials, reviewed by multiple government agencies (as discussed above), and demonstrated to be safe before entering the market.

\section{Grower and Consumer Perceptions of Biotech Potato}

For a biotech potato to be a market success it must be accepted by the government, producers, and consumers. The government approval process for Simplot Innate ${ }^{\mathrm{TM}} 1.0$ took 2 years; Amflora in Europe took 13 years. Many biotechnology scientists and advocates claim that the regulatory process for all biotech crops is overly burdensome and should be streamlined.

Producer acceptance of biotechnology can be quite rapid if the new product solves a production problem. NewLeaf ${ }^{\mathrm{TM}}$ potato plantings increased quickly in areas where $\mathrm{CPB}$ was a problem. Even when biotech potatoes were not available, producers were willing to use them again. In a 2010 survey of people in the North American potato industry Toevs et al. (2011a) found that $90 \%$ of respondents agreed or strongly agreed with the statement that potatoes with traits from potato DNA will be accepted by potato growers. For transgenic potatoes only $62 \%$ agreed or strongly agreed.

"Consumer is King" is an economic principle that says consumer preferences determine the production of goods and services (Hutt 1937). Consumers in supermarkets, quick service restaurants, and other places where potatoes are sold will determine the success or failure of biotech potato products. Consumer research can provide insight into how the consumers might respond to biotech potatoes entering the market.

Hoban (1999) found that consumers in Japan and the U.S. were optimistic about biotechnology. In both countries, among six types of food safety risks, pesticide residues caused the most concern and biotechnology the least. Those results suggest a market opportunity for biotech potatoes that require less pesticide. However, NewLeaf ${ }^{\mathrm{TM}}$ potatoes, though they required less pesticide, were ultimately not accepted in the marketplace, largely due to activist pressure on the brands of 
major potato product retailers, leading to the belief that societal acceptance of new technology follows predictable patterns and that more time was needed for acceptance of biotech potatoes after their release (Guenthner 2002).

Following the market withdrawal of biotech potatoes, some researchers included potato products in their consumer biotech-acceptance studies. In one, $86 \%$ of Canadian consumers said that they would be willing to pay a price premium for "heart-healthy" biotech potato chips (West et al. 2002). Others found that consumers would pay higher prices for potato chips labeled as GM-free (VanWechel et al. 2003). Consumers given more information, whether negative or positive about biotech, increased the price they would pay for chips presumed to have been made with biotech potatoes.

Loureiro and Hine (2002) studied consumer willingnessto-pay for three types of fresh potatoes: organic, local, and GM-free. They were willing to pay the highest premium for locally produced potatoes and the lowest premium for GMfree potatoes. Huffman (2003) conducted experimental auctions for three food products - vegetable oil, tortilla chips, and fresh russet potatoes, and found that consumers were willing to pay more for biotech-free products. Information from environmental groups reduced the amount consumers would pay for biotech potato, but those differences disappeared when participants were given verifiable, third-party information that disputed the environmental groups' claims (Huffman et al. 2004). Rousu et al. (2003) found that participants would pay less for potatoes that contained some biotech content, but that there was no difference in values between products with 1 and $5 \%$ tolerance level for biotech content.

Lusk and Sullivan (2002) asked consumers about willingness to eat a vegetable transformed with seven different types of genes. At the low end, acceptance for using genes from a virus, fungus, bacteria, or animal ranged from 14 to $23 \%$. At the high end, $81 \%$ would accept a product that used genes from the same vegetable.

NewLeaf ${ }^{\mathrm{TM}}$ potatoes were prematurely cited as a success story for effective biotech marketing (Phillips and Corkindale 2002). In 1999 Monsanto began a marketing campaign in Prince Edward Island (PEI), where pesticides applied to potato fields had leached into rivers and coastal waters, resulting in fish kills. Focusing on the reduction of insecticide use for NewLeaf ${ }^{\mathrm{TM}}$ potatoes, Monsanto proactively marketed their biotech fresh potatoes as an environmentally friendly product. They made biotech fresh potatoes available in PEI grocery stores and used advertising, publicity, point-of-sale information, and a toll-free phone line as marketing tools. Even with premium prices, the entire crop of biotech fresh potatoes quickly sold out. The next year a major potato processor and a buyer of PEI potatoes announced that they would stop buying biotech potatoes because of perceived consumer resistance. Although biotech potatoes were successful in the fresh market, the lack of support in the processing industry contributed to the withdrawal of biotech potatoes from the entire North American market.

Future market acceptance of biotech potato will be influenced by the type of biotechnology used to develop new products. Anti-GM activists often define GM as transferring DNA from one species to another. Since techniques like gene editing may not fit that definition, non-government organizations that are outspoken opponents of transgenics may be open to support of other types of biotech potatoes. Simplot's Innate ${ }^{\mathrm{TM}}$ potatoes with traits introduced from potato DNA will soon test that hypothesis in the North American market. Perhaps others may soon begin testing in Europe: the Dutch government recently made a commitment to provide 10 million euros per year to a public/private research group for tomato and potato breeding. That investment could have come about only with some optimism that non-transgenic biotechnology will be treated favorably in the EU regulatory system.

Gene-editing and biotechnology using traits from the same species could alter the discussions regarding labeling of food products derived from biotech crops. Debates about biotech labeling typically include a focus on the breeding tool rather than the product. If labeling of products derived from biotech crops becomes mandatory, this could simply provide an opportunity to publicize the benefits of biotech potatoes. The current US system of voluntary labeling that allows food manufacturers to use GM-Free labels could also help bring price premiums to labeled biotech potatoes that have traits popular with consumers. One way to help that happen could be to use different terminology on labels. Unfortunately, the terms GM and GMO have become pejoratives in the popular press. For consumer acceptance purposes, less disparaging terms, such as 'biotech' or 'genetically enhanced', could replace GM while still conveying the intended meaning.

At the time of the writing of this review article, the U.S. congress is in the process of discussing the Safe and Accurate Food Labeling Act. This bill amends the Federal Food, Drug, and Cosmetic Act to require the Food and Drug Administration (FDA) to continue the voluntary consultation process established under the FDA to evaluate a scientific and regulatory assessment provided by the biotech food developer.

The FDA may require a biotech food to have a label that informs consumers of any material difference between the biotech food and a comparable food. But, the use of biotechnology to develop food does not, by itself, constitute a material difference, and biotech food developers may voluntarily disclose how a product has been genetically engineered, but they are not required to do so under the bill. The bill also will preempt state and local restrictions on GMO food and labeling requirements, which have appeared in several locations throughout the U.S. 


\section{Benefits of Biotech Potato}

NatureMark potatoes provided benefits to farmers, processors, consumers, and the environment. Growers who planted NewLeaf ${ }^{\mathrm{TM}}$ potatoes reduced insecticide expenditures and increased revenue due to higher yields and better quality. According to Kaniewski and Thomas (2004), Idaho growers saved $\$ 350$ per hectare on their NewLeaf Plus ${ }^{\mathrm{TM}}$ plantings and growers in the Columbia Basin saved $\$ 405$ per hectare. Processors benefitted from a higher quality raw product free of net necrosis (internal discoloring). Consumers enjoyed higher quality potato products at no increase in costs.

The environment benefitted because nearly two million pounds of insecticides and 30,000 spray plane sorties were not needed on the NewLeaf ${ }^{\mathrm{TM}}$ fields in the Pacific Northwest (Kaniewski and Thomas 2004). For the whole U.S. potato crop, the NewLeaf ${ }^{\mathrm{TM}}$ potatoes could significantly reduce the 2.6 million pounds of pesticides applied each year (Phipps and Park 2002; Brookes and Barfoot 2005). Other researchers confirmed that biotech potatoes could decrease pesticide use and increase grower profits (Marra et al. 2002; Flannery et al. 2004).

Less pesticide use and reduced crop losses through biotechnology also appeal to potato growers in developing countries (Curtis et al. 2004; Huesing and English 2004). Biotech potatoes developed at Michigan State University were field tested in South Africa and Egypt and found to control Potato Tuber Moth (PTM), a pest that can cause severe losses in yield and quality. Researchers found the PTM-resistant potatoes could increase food security, reduce food prices, increase farm profitability, and protect the environment in those two countries (Guenthner et al. 2004). Growers in South Africa could save the costs of applying nine different insecticides that are typically used to control PTM. Resource-poor farmers who cannot afford pesticides would benefit from better yields and quality.

Some of the economic and environmental benefits of potatoes with late blight resistance, low acrylamide potential, reduced black spot, and lowered reducing sugars potatoes were estimated by Guenthner (unpublished 2015). In addition to these traits, benefits include reduced potato waste, better fresh pack-out and increased grower profits. Estimates of the impacts of the black spot bruise, blight, and storage traits are shown in Table 1 and discussed below.

Fresh Potato Black Spot Bruise We estimated impacts on U.S. fresh potato growers, packers, retailers and foodservice if all fresh potatoes ( $24 \%$ of the U.S. crop) had the black spot bruise resistant trait. Interviews with fresh potato experts provided estimates of the amount of waste due to black spot bruise that would be reduced with this trait. Using 2013 crop data, we estimated that 1.9 million metric tonnes $(\mathrm{mmt})$ of potatoes would not be lost. At the 2013 average potato yield, that meant that 8,600 fewer hectares would need to be planted to produce the same size crop. This translates to 145,000 hectares of potato that would no longer require pesticide applications. Using metrics from Field to Market (2015), we estimated that $0.3 \mathrm{mmt}$ pounds of $\mathrm{CO}_{2}$ and 55 billion liters of water would be saved.

Late Blight We also estimated potential impacts of late blight resistance for the entire U.S. potato industry. Expert opinion research provided data on potential fungicide reduction due to the late blight resistance trait. Research by Guenthner et al. (2001) provided estimates of reduced late blight yield loss $(5 \%)$ and storage loss $(1.7 \%)$. We estimated that $6.4 \mathrm{mmt}$ of waste and yield loss would be reduced, the equivalent of 28 , 900 hectares. Potato pesticide hectare-applications would be reduced by 492,000 . Using Field to Market metrics, we estimated a savings of $1.0 \mathrm{mmt}$ of $\mathrm{CO}_{2}$ emissions and 186 billion liters of water. Actual savings will depend on regulatory clearance and adoption of late blight resistant varieties.

Processed Potato Storage We estimated impacts of cold storage on the U.S. potato crop that goes into processing. USDA data revealed that $89 \%$ of the U.S. potato crop was harvested in the fall. Using USDA monthly sales data we estimated that $81 \%$ of the fall crop is stored. Research by Patterson (2013) provided information on Chlorpropham (CIPC) application timing and costs. Research by Sparks and Summers (1974) was the source of data for cold storage savings in potato shrink and loss for each month of storage. We estimated that $2.6 \mathrm{mmt}$ of potatoes would not be lost if all stored processed potatoes had the cold storage trait. The reduced waste is the amount that could be grown on 11,300 hectares. Pesticide application would decline by 370,000 hectare-applications. $\mathrm{CO}_{2}$ emissions would decline by $0.4 \mathrm{mmt}$ and water use would drop by 76 billion liters. A large, but undetermined share of those benefits would come from Russet Burbank, the dominant variety in frozen processing.

Costs We estimated the economic impact of potato varieties with late blight resistance, low acrylamide potential, reduced black spot, and lowered reducing sugars, on production costs for typical Eastern Idaho russet potato growers. Operating costs per hectare, excluding any changes in seed potato costs, could be expected to decline $12 \%$. Due to higher marketable yields and less waste, operating costs per tonne would go down $28 \%$.

Alternate Crops This analysis involved estimates of potato hectares not planted. Due to reduced shrink, loss and waste, reduced plantings could produce the same total quantity. The above estimates do not account for the crops that growers would plant instead of potatoes. Since small grains is a common rotation crop for many potatoes growers, it is likely that 
Table 1 Estimated economic and sustainability benefits of potatoes with late blight resistance, low acrylamide potential, reduced black spot, and lowered reducing sugars

\begin{tabular}{lllll}
\hline Item & Bruise & Blight & Storage & Total \\
\hline Market & Fresh & All & Processed & N/A \\
Potato waste reduced (million metric tonnes) & 1.9 & 6.4 & 2.6 & 10.9 \\
$\mathrm{CO}_{2}$ emissions reduced (million metric tonnes) & 0.3 & 1.0 & 0.4 & 1.6 \\
Water use reduced (billion liters) & 55 & 186 & 76 & 316 \\
Pesticide applications reduced (hectares) & 145,000 & 492,000 & 370,000 & $1,007,000$ \\
Potato plantings not needed (hectares) & 8,600 & 28,900 & 11,300 & 48,800 \\
Costs of production saved (million US\$) & $\$ 42$ & $\$ 141$ & $\$ 55$ & $\$ 238$ \\
\hline
\end{tabular}

some plantings would shift from potatoes to grain. For each hectare shifted to small grains by typical Eastern Idaho potato growers, production costs go down an estimated $\$ 3,900$, and $\mathrm{CO}_{2}$ emissions would decrease $56 \%$.

Directed Marketing Stewardship Although we did not attempt to estimate its value, enhanced stewardship is an additional benefit that with the introduction of biotech into potato markets. One of the unrecognized needs for NatureMark ${ }^{\mathrm{TM}}$ potatoes was a directed marketing approach to guide the flow of biotech product into intended markets and away from international market channels. Simplot has developed a closed loop system to reduce that risk, pending completion of international approvals. Described as a risk-based system that directs potatoes to intended markets, the program restricts handling of Innate ${ }^{\mathrm{TM}}$ potatoes to licensed growers, packers, processors, and distributors. Within the program is a list of production practices, including such things as equipment clean-out and cull disposal for the licensees in the Innate $^{\mathrm{TM}}$ supply chain. From an analysis of certified seed potato variety purity, Guenthner et al. (2012) concluded that if commercial growers used identity preservation production practices employed by seed potato growers, biotech potato content could be well within Japan's expected import tolerance of $5 \%$ biotech to trigger labeling requirements, once events are approved in Japan.

\section{Future Prospects}

The mass selection breeding method used by many potato breeders has changed little over the past century. Despite this, the overall yield of potato crops in the U.S. has steadily increased. The average yield of potatoes in 2014 was $426 \mathrm{cwt} /$ acre compared to $66 \mathrm{cwt} /$ acre in 1930, an increase of $630 \%$ (NASS 2015). The expansion of genomic resources for potato and the application of these resources towards the improvement of new varieties and germplasm has been an area of intensive study over the past 20 years. While increased yield remains a primary focus for most breeders, the development of potato that requires fewer inputs and possesses wider environmental adaptability will allow the crop to continue to grow as a significant and nutritional food source worldwide. Biotechnology provides reliable and rapid methods for the incorporation of traits (genes) that are realized through the use of expanding genomic resources. Potato was one of the first crops to be genetically modified, and it remains at the forefront of biotechnology research due in part to its rapid regeneration and resilience after being subjected to tissue culture. As new tools are developed for efficient and specific editing of the potato genome, more complex challenges can be approached, leading to continued crop improvement and scientific achievements.

The apparent impacts that biotech potato could have on enhanced nutrition, reduced pesticide applications, and decreased food waste, have been perceived positively by consumers in the U.S. These perceptions can differ widely in other parts of the world, and have led to the expansion of biotech potato development in some areas and elimination in others. A continued focus on improvements that directly benefit consumers will be important to the viability of biotech potato in the marketplace. In addition to agronomic and nutrition benefits described in this review, non-food applications of biotech potato for industrial, pharmaceutical, and veterinary purposes could also benefit consumers through decreased manufacturing costs and increased functionality of therapeutic molecules (review by Rigano et al. 2013) or starch-derived polymers (Neumann et al. 2005; Hühns et al. 2009). As research continues to identify and address challenges associated with potato production, we predict a corresponding invention of products that will advance the industry. With the help of biotechnology, we hope that science will continue to provide increased value and quality of potato products without changing consumer's perceptions of the "humble spud" that is so well recognized and welcomed at dinner tables throughout the world. 
Acknowledgments Salary funding for N. Butler was provided by USDA Biotechnology Risk Assessment Grant number 2013-3352221090.

Open Access This article is distributed under the terms of the Creative Commons Attribution 4.0 International License (http:// creativecommons.org/licenses/by/4.0/), which permits unrestricted use, distribution, and reproduction in any medium, provided you give appropriate credit to the original author(s) and the source, provide a link to the Creative Commons license, and indicate if changes were made.

\section{References}

Bachem, C.W.B., G.-J. Speckmann, P.C.G. van der Linde, F.T.M. Verheggen, M.D. Hunt, J.C. Steffens, and M. Zabeau. 1994. Antisense expression of polyphenol oxidase genes inhibits enzymatic browning in potato tubers. Nature Biotechnology 12: 1101-1105.

Ballvora, A., M.R. Ercolano, J. Weiss, K. Meksem, C.A. Bormann, P. Oberhagemann, F. Salamini, and C. Gebhardt. 2002. The R1 gene for potato resistance to late blight (Phytophthora infestans) belongs to the leucine zipper/NBS/LRR class of plant resistance genes. Plant Journal 30: 361-371.

BASF. 2013. BASF to expand its plant biotechnology research into fungal resistance in corn.

Baum, J.A., T. Bogaert, W. Clinton, G.R. Heck, P. Feldmann, O. Ilagan, S. Johnson, G. Plaetinck, T. Munyikwa, M. Pleau, T. Vaughn, and J. Roberts. 2007. Control of coleopteran insect pests through RNA interference. Nature Biotechnology 25: 1322-1326.

Becalski, A., B.P. Lau, D. Lewis, and S.W. Seaman. 2003. Acrylamide in foods: occurrence, sources, and modeling. Journal of Agricultural and Food Chemistry 51: 802-808.

Bendahmane, M., J.H. Fitchen, G.M. Zhang, and R.N. Beachy. 1997. Studies of coat protein-mediated resistance to tobacco mosaic tobamovirus: correlation between assembly of mutant coat proteins and resistance. Journal of Virology 71: 7942-7950.

Bendahmane, A., M. Querci, K. Kanyuka, and D.C. Baulcombe. 2000. Agrobacterium transient expression system as a tool for the isolation of disease resistance genes: application to the $R \times 2$ locus in potato. Plant Journal 21: 73-81.

Benzing-Purdie, L.M., J.A. Ripmeester, and C.I. Ratcliffe. 1985. Effects of temperature on Maillard reaction products. Journal of Agricultural and Food Chemistry 33: 31-33.

Bhaskar, P.B., L. Wu, J.S. Busse, B.R. Whitty, A.J. Hamernik, S.H. Jansky, C.R. Buell, P.C. Bethke, and J. Jiang. 2010. Suppression of the vacuolar invertase gene prevents cold-induced sweetening in potato. Plant Physiology 154: 939-948.

Bouwmeester, K., M. Han, R. Blanco-Portales, W. Song, R. Weide, L.-Y. Guo, E.A.G. van der Vossen, and F. Govers. 2014. The Arabidopsis lectin receptor kinase LecRK-I.9 enhances resistance to Phytophthora infestans in Solanaceous plants. Plant Biotechnology Journal 12: 10-16.

Brookes, G., and P. Barfoot. 2005. GM crops: the global socio-economic and environmental impact - the first nine years 1996-2004.

Brown, C.R., C.G. Edwards, C.-P. Yang, and B.B. Dean. 1993. Orange flesh trait in potato: Inheritance and carotenoid content. Journal of the American Society for Horticultural Science 118: 145-150.

Bulley, S., M. Wright, C. Rommens, H. Yan, M. Rassam, K. Lin-Wang, C. Andre, D. Brewster, S. Karunairetnam, A.C. Allan, and W.A. Laing. 2012. Enhancing ascorbate in fruits and tubers through over-expression of the L-galactose pathway gene GDP-L-galactose phosphorylase. Plant Biotechnology Journal 10: 390-397.

Bushey, D.F., G.A. Bannon, B.F. Delaney, G. Graser, M. Hefford, X. Jiang, T.C. Lee, K.M. Madduri, M. Pariza, L.S. Privalle, R.
Ranjan, G. Saab-Rincon, B.W. Schafer, J.J. Thelen, J.X. Zhang, and M.S. Harper. 2014. Characteristics and safety assessment of intractable proteins in genetically modified crops. Regulatory Toxicology and Pharmacology 69: 154-170.

Cabello, R., F. De Mendiburu, M. Bonierbale, P. Monneveux, W. Roca, and E. Chujoy. 2012. Large-scale evaluation of potato improved varieties, genetic stocks and landraces for drought tolerance. American Journal of Potato Research 89: 400-410.

Cavatorta, J., K.W. Perez, S.M. Gray, J. Van Eck, I. Yeam, and M. Jahn. 2011. Engineering virus resistance using a modified potato gene. Plant Biotechnology Journal 9: 1014-1021.

Chakravarty, B., G. Wang-Pruski, B. Flinn, V. Gustafson, and S. Regan. 2007. Genetic transformation in potato: approaches and strategies. American Journal of Potato Research 84: 301-311.

Chawla, R., R. Shakya, and C.M. Rommens. 2012. Tuber-specific silencing of asparagine synthetase- 1 reduces the acrylamide-forming potential of potatoes grown in the field without affecting tuber shape and yield. Plant Biotechnology Journal 10: 913-924.

Chi, M., B. Bhagwat, W.D. Lane, G. Tang, Y. Su, R. Sun, B.D. Oomah, P.A. Wiersma, and Y. Xiang. 2014. Reduced polyphenol oxidase gene expression and enzymatic browning in potato (Solanum tuberosum L.) with artificial microRNAs. BMC Plant Biology 14: 62.

Clasen, B.M., T.J. Stoddard, S. Luo, Z.L. Demorest, J. Li, F. Cedrone, R. Tibebu, S. Davison, E.E. Ray, A. Daulhac, A. Coffman, A. Yabandith, A. Retterath, W. Haun, N.J. Baltes, L. Mathis, D.F. Voytas, and F. Zhang. 2015. Improving cold storage and processing traits in potato through targeted gene knockout. Plant Biotechnology Journal. doi:10.1111/pbi.12370.

Coetzer, C., D. Corsini, S. Love, J. Pavek, and N. Tumer. 2001. Control of enzymatic browning in potato (Solanum tuberosum L.) by sense and antisense RNA from tomato polyphenol oxidase. Journal of Agricultural and Food Chemistry 49: 652-657.

Conner, A.J., and P.J. Dale. 1996. Reconsideration of pollen dispersal data from field trials of transgenic potatoes. Theoretical and Applied Genetics 92: 505-508.

Curtis, K., J. McCluskey, and T. Wahl. 2004. Consumer acceptance of genetically modified food products in the developing world. AgBioforum 7: 70-75.

Dale, P.J. 1992. Spread of engineered genes to wild relatives. Plant Physiology 100: 13-15.

Du, J., E. Verzaux, A. Chaparro-Garcia, G. Bijsterbosch, L.C.P. Keizer, J. Zhou, T.W.H. Liebrand, C. Xie, F. Govers, S. Robatzek, E.A.G. van der Vossen, E. Jacobsen, R.G.F. Visser, S. Kamoun and V.G.A.A. Vleeshouwers. 2015. Elicitin recognition confers enhanced resistance to Phytophthora infestans in potato. Nature Plants 1.

Duan, H., C. Richael, and C. Rommens. 2012. Overexpression of the wild potato $e I F 4 E-1$ variant $E v a l$ elicits Potato virus Y resistance in plants silenced for native eIF4E-1. Transgenic Research 21: 929 938.

Duan, H., A. Forsyth, T. Weeks and C. Richael. 2014. TAL-mediated targeted DNA integration in potato plants. 98th Annual Meeting of the Potato Association of America.

Eijlander, R., and W. Stiekema. 1994. Biological containment of potato (Solanum tuberosum): outcrossing to the related wild species black nightshade (Solanum nigrum) and bittersweet (Solanum dulcamara). Sexual Plant Reproduction 7: 29-40.

Fairbairn, D.J., A.S. Cavallaro, M. Bernard, J. Mahalinga-Iyer, M.W. Graham, and J.R. Botella. 2007. Host-delivered RNAi: an effective strategy to silence genes in plant parasitic nematodes. Planta 226: $1525-1533$.

FDA. 2015. http://www.accessdata.fda.gov/scripts/fdcc/?set=Biocon. Accessed 15 May 2015.

Field to Market. 2015. Fieldprint calculator. https://www.fieldtomarket.org/. Accessed 22 May 2015. 
Flannery, M., F. Thorne, P. Kelley, and E. Mullins. 2004. An economic cost-benefit analysis of GM crop cultivation: and Irish case study. AgBioforum 7: 149-157.

Foster, S.J., T.-H. Park, M. Pel, G. Brigneti, J. Śliwka, L. Jagger, E. van der Vossen, and J.D.G. Jones. 2009. Rpi-vnt1.1, a Tm-22 homolog from Solanum venturii, confers resistance to potato late blight. Molecular Plant-Microbe Interactions 22: 589-600.

Fradin, E.F., Z. Zhang, J.C. Juarez Ayala, C.D.M. Castroverde, R.N. Nazar, J. Robb, C.-M. Liu, and B.P.H.J. Thomma. 2009. Genetic dissection of Verticillium wilt resistance mediated by tomato Vel . Plant Physiology 150: 320-332.

Gao, Z., E. Johansen, S. Eyers, C.L. Thomas, T.H. Noel Ellis, and A.J. Maule. 2004. The potyvirus recessive resistance gene, sbml, identifies a novel role for translation initiation factor eIF4E in cell-to-cell trafficking. The Plant Journal 40: 376-385.

Ghag, S.B., U.K. Shekhawat, and T.R. Ganapathi. 2014. Host-induced post-transcriptional hairpin RNA-mediated gene silencing of vital fungal genes confers efficient resistance against Fusarium wilt in banana. Plant Biotechnology Journal 12: 541-553.

Goldbach, R., E. Bucher, and M. Prins. 2003. Resistance mechanisms to plant viruses: an overview. Virus Research 92: 207-212.

Gonsalves, D. 1998. Control of papaya ringspot virus in papaya: a case study. Annual Review of Phytopathology 36: 415-437.

Gonsalves, D., C. Gonsalves, S. Ferreira, K. Pitz, M. Fitch, R. Manshardt, and J. Slightom. 2004. Transgenic virus resistant papaya: from hope to reality for controlling Papaya ringspot virus in Hawaii. APSnet Features. doi:10.1094/APSnetFeature-2004-0704.

Govindarajulu, M., L. Epstein, T. Wroblewski and R.W. Michelmore. 2014. Host-induced gene silencing inhibits the biotrophic pathogen causing downy mildew of lettuce. Plant Biotechnology Journal.

Gregory, P., S.L. Sinden, S.F. Osman, W.M. Tingey, and D.A. Chessin. 1981. Glycoalkaloids of wild, tuber-bearing Solanum species. Journal of Agricultural and Food Chemistry 29: 1212-1215.

Guenthner, J. 2001. The international potato industry. Woodhead Publishing, Cambridge UK.

Guenthner, J. 2002. Consumer acceptance of genetically modified potatoes. American Journal of Potato Research 79: 309-315.

Guenthner, J., K. Michael, and P. Nolte. 2001. Potato late blight's impact on growers. Potato Research 44: 121-125.

Guenthner, J., A. Araji, and K. Maredia. 2004. Benefits of public investment in potato biotechnology for developing countries. Applied Biotechnology, Food Science and Policy 1: 235-242.

Guenthner, J.F., A.J. Johnson, and C.S. McIntosh. 2012. Seed variety mix: an indicator for GM potato identity preservation. American Journal of Potato Research 89: 172-174.

Hamilton, C.M., A. Frary, C. Lewis, and S.D. Tanksley. 1996. Stable transfer of intact high molecular weight DNA into plant chromosomes. Proceedings of the National Academy of Sciences 93: 99759979.

Hamilton, J.P., C.N. Hansey, B.R. Whitty, K. Stoffel, A.N. Massa, A. Van Deynze, W.S. De Jong, D.S. Douches, and C.R. Buell. 2011. Single nucleotide polymorphism discovery in elite north american potato germplasm. BMC Genomics 12: 302-313.

Hanneman Jr., R.E. 1989. The potato germplasm resource. The American Potato Journal 66: 655-667.

Haun, W., A. Coffman, B.M. Clasen, Z.L. Demorest, A. Lowy, E. Ray, A. Retterath, T. Stoddard, A. Juillerat, F. Cedrone, L. Mathis, D.F. Voytas, and F. Zhang. 2014. Improved soybean oil quality by targeted mutagenesis of the fatty acid desaturase 2 gene family. Plant Biotechnology Journal 12: 934-940.

Hemavathi, C., N. Upadhyaya, K. Akula, S. Young, D. Kim Chun, and S. Park. 2010. Enhanced ascorbic acid accumulation in transgenic potato confers tolerance to various abiotic stresses. Biotechnology Letters 32: 321-330.

Hijmans, R.J., and D.M. Spooner. 2001. Geographic distribution of wild potato species. American Journal of Botany 88: 2101-2112.
Hirsch, C.N., C.D. Hirsch, K. Felcher, J. Coombs, D. Zarka, A. van Deynze, W. de Jong, R. Veilleux, S. Jansky, P. Bethke, D.S. Douches, and C.R. Buell. 2013. Retrospective view of North American potato (Solanum tuberosum L.) breeding in the 20th and 21st centuries. G3: Genes, Genomes, Genetics 3:1003-1013.

Hoban, T. 1999. Consumer acceptance of biotechnology in the United States and Japan. Food Technology 53: 50-54.

Huang, S., E.A.G. van der Vossen, H. Kuang, V.G.A.A. Vleeshouwers, N. Zhang, T.J.A. Borm, H.J. van Eck, B. Baker, E. Jacobsen, and R.G.F. Visser. 2005. Comparative genomics enabled the isolation of the R3a late blight resistance gene in potato. The Plant Journal 42: 251-261.

Huang, G., R. Allen, E.L. Davis, T.J. Baum, and R.S. Hussey. 2006. Engineering broad root-knot resistance in transgenic plants by RNAi silencing of a conserved and essential root-knot nematode parasitism gene. Proceedings of the National Academy of Sciences of the United States of America 103: 14302-14306.

Huesing, J., and L. English. 2004. The impact of Bt crops on the developing world. AgBioforum 7: 84-95.

Huffman, W. 2003. Consumers' acceptance of (and resistance to) genetically modified foods in high-income countries: effects of labels and information in an uncertain environment. American Journal of Agricultural Economics 85: 1112-1118.

Huffman, W., J. Shogren, M. Rousu, and A. Tegene. 2004. Consumer willingness to pay for genetically modified food labels in a market with diverse information: evidence from experimental auctions. Journal of Agricultural and Resource Economics 28: 481-502.

Hühns, M., K. Neumann, T. Hausmann, F. Klemke, W. Lockau, U. Kahmann, L. Kopertekh, D. Staiger, E.K. Pistorius, J. Reuther, E. Waldvogel, W. Wohlleben, M. Effmert, H. Junghans, K. Neubauer, U. Kragl, K. Schmidt, J. Schmidtke, and I. Broer. 2009. Tuberspecific cphA expression to enhance cyanophycin production in potatoes. Plant Biotechnology Journal 7: 883-898.

Hutt, W. 1937. Economists and the Public.

Huvenne, H., and G. Smagghe. 2010. Mechanisms of dsRNA uptake in insects and potential of RNAi for pest control: a review. Journal of Insect Physiology 56: 227-235.

Ibiza, V., J. Canizares, and F. Nuez. 2010. EcoTILLING in Capsicum species: searching for new virus resistances. BMC Genomics 11: 631.

ISAAA. 2015. Potato (Solanum tuberosum L.) GM events. http://www. isaaa.org/gmapprovaldatabase/crop/default.asp?Crop ID= 16\&Crop=Potato. Accessed 22 May 2015.

Jahan, S.N., A.K. Asman, P. Corcoran, J. Fogelqvist, R.R. Vetukuri, and C. Dixelius. 2015. Plant-mediated gene silencing restricts growth of the potato late blight pathogen Phytophthora infestans. Journal of Experimental Botany 66: 2785-2794.

James, C. 2014. Global status of commercialized biotech/GM crops. ISAAA Brief No. 49-2014.

Jansky, S. 2000. Breeding for disease resistance in potato. Plant Breeding Reviews 19: 69-155.

Jones, D.A., C.M. Thomas, K.E. Hammond-Kosack, P.J. Balint-Kurti, and J.D. Jones. 1994. Isolation of the tomato $C f-9$ gene for resistance to Cladosporium fulvum by transposon tagging. Science 266: 789793.

Jones, J., S.J. Foster, Z. Chu, T.-H. Park, V.D.V.E.A. G, M.A. Pel and R.G.F. Visser. 2009. Late blight resistance genes and methods.

Kang, B.-C., I. Yeam, J.D. Frantz, J.F. Murphy, and M.M. Jahn. 2005. The pvrl locus in Capsicum encodes a translation initiation factor eIF4E that interacts with tobacco etch virus VPg. The Plant Journal 42: 392-405.

Kang, B.C., I. Yeam, H.X. Li, K.W. Perez, and M.M. Jahn. 2007. Ectopic expression of a recessive resistance gene generates dominant potyvirus resistance in plants. Plant Biotechnology Journal 5: $526-536$ 
Kaniewski, W., and P. Thomas. 2004. The potato story. AgBioforum 7: 41-46.

Kanyuka, K., A. Druka, D.G. Caldwell, A. Tymon, N. McCallum, R. Waugh, and M.J. Adams. 2005. Evidence that the recessive bymovirus resistance locus rym 4 in barley corresponds to the eukaryotic translation initiation factor $4 \mathrm{E}$ gene. Molecular Plant Pathology 6: 449-458.

Kawchuk, L.M., J. Hachey, D.R. Lynch, F. Kulcsar, G. van Rooijen, D.R. Waterer, A. Robertson, E. Kokko, R. Byers, R.J. Howard, R. Fischer, and D. Prufer. 2001. Tomato Ve disease resistance genes encode cell surface-like receptors. Proceedings of the National Academy of Sciences of the United States of America 98: 6511-6515.

Kierzkowski, D., M. Kmieciak, P. Piontek, P. Wojtaszek, Z. Szweykowska-Kulinska, and A. Jarmolowski. 2009. The Arabidopsis CBP20 targets the cap-binding complex to the nucleus, and is stabilized by CBP80. The Plant Journal 59: 814-825.

Kim, H.J., K.H. Baek, B.W. Lee, D. Choi, and C.G. Hur. 2011. In silico identification and characterization of microRNAs and their putative target genes in Solanaceae plants. Genome 54: 91-98.

Koch, A., N. Kumar, L. Weber, H. Keller, J. Imani, and K.H. Kogel. 2013. Host-induced gene silencing of cytochrome P450 lanosterol C14alpha-demethylase-encoding genes confers strong resistance to Fusarium species. Proceedings of the National Academy of Sciences of the United States of America 110: 19324-19329.

Lacombe, S., A. Rougon-Cardoso, E. Sherwood, N. Peeters, D. Dahlbeck, H.P. van Esse, M. Smoker, G. Rallapalli, B.P.H.J. Thomma, B. Staskawicz, J.D.G. Jones, and C. Zipfel. 2010. Interfamily transfer of a plant pattern-recognition receptor confers broad-spectrum bacterial resistance. Nature Biotechnology 28: 365 369.

Liu, Z., and D. Halterman. 2006. Identification and characterization of $R B$ orthologous genes from the late blight resistant wild potato species Solanum verrucosum. Physiological and Molecular Plant Pathology 69: 230-239.

Lokossou, A.A., T.-h. Park, G. van Arkel, M. Arens, C. Ruyter-Spira, J. Morales, S.C. Whisson, P.R.J. Birch, R.G.F. Visser, E. Jacobsen, and E.A.G. van der Vossen. 2009. Exploiting knowledge of $R / A v r$ genes to rapidly clone a new LZ-NBS-LRR family of late blight resistance genes from potato linkage group IV. Molecular Plant-Microbe Interactions 22: 630-641.

Loureiro, M. and S. Hine. 2002. Discovering niche markets: a comparison of consumer willingness to pay for local, organic and GMO-free products. Journal of Agricultural and Applied Economics 34.

Love, S. 1994. Ecological risk of growing transgenic potatoes in the United States and Canada. American Potato Journal 71: 647-658.

Lusk, J., and P. Sullivan. 2002. Consumer acceptance of genetically modified foods. Food Technology 56: 32-37.

Mackerron, D.K.L., and R.A. Jefferies. 1988. The distributions of tuber sizes in droughted and irrigated crops of potato. I. Observations on the effect of water stress on graded yields from differing cultivars. Potato Research 31: 269-278.

Marra, M., P. Pardey, and J. Alston. 2002. The payoffs to transgenic field crops: an assessment of the evidence. AgBioforum 5: 43-50.

McCue, K.F., L.V.T. Shepherd, P.V. Allen, M.M. Maccree, D.R. Rockhold, D.L. Corsini, H.V. Davies, and W.R. Belknap. 2005. Metabolic compensation of steroidal glycoalkaloid biosynthesis in transgenic potato tubers: using reverse genetics to confirm the in vivo enzyme function of a steroidal alkaloid galactosyltransferase. Plant Science 168: 267-273.

McDougall, P. 2011. The cost and time involved in the discovery, development and authorisation of a new plant biotechnology derived trait. A Consultancy Study for Crop Life International.

McKenzie, M.J., R.K. Chen, J.C. Harris, M.J. Ashworth, and D.A. Brummell. 2013. Post-translational regulation of acid invertase activity by vacuolar invertase inhibitor affects resistance to coldinduced sweetening of potato tubers. Plant, Cell \& Environment 36: $176-185$.

McPartlan, H., and P. Dale. 1994. An assessment of gene transfer by pollen from field-grown transgenic potatoes to non-transgenic potatoes and related species. Transgenic Research 3: 216-225.

Michelmore, R.W., and B.C. Meyers. 1998. Clusters of resistance genes in plants evolve by divergent selection and a birth-and-death process. Genome Research 8: 1113-1130.

Miller, J., and K. Bradford. 2010. The regulatory bottleneck for biotech specialty crops. Nature Biotechnology 28: 1012-1014.

Monneveux, P., D.A. Ramirez, and M.T. Pino. 2013. Drought tolerance in potato $(S$. tuberosum L.): can we learn from drought tolerance research in cereals? Plant Science 205-206: 76-86.

Naderpour, M., O.L.E.S. Lund, R. Larsen, and E. Johansen. 2010. Potyviral resistance derived from cultivars of Phaseolus vulgaris carrying $b c-3$ is associated with the homozygotic presence of a mutated eIF4E allele. Molecular Plant Pathology 11: 255-263.

NASS. 2015. National Agricultural Statistics Service. http://www.nass.usda. gov/Statistics_by_Subject/index.php?sector=CROPS. Accessed 15 May 2015.

National Toxicology Program. 2011. Report on Carcinogens, Twelfth Edition. http://ntp.niehs.nih.gov/ntp/roc/twelfth/profiles/ Acrylamide.pdf. Accessed 15 May 2015.

Neumann, K., D.P. Stephan, K. Ziegler, M. Huhns, I. Broer, W. Lockau, and E.K. Pistorius. 2005. Production of cyanophycin, a suitable source for the biodegradable polymer polyaspartate, in transgenic plants. Plant Biotechnology Journal 3: 249-258.

Nicaise, V., S. German-Retana, R. Sanjuán, M.-P. Dubrana, M. Mazier, B. Maisonneuve, T. Candresse, C. Caranta, and O. LeGall. 2003. The eukaryotic translation initiation factor $4 \mathrm{E}$ controls lettuce susceptibility to the potyvirus lettuce mosaic virus. Plant Physiology 132: $1272-1282$.

Nieto, C., M. Morales, G. Orjeda, C. Clepet, A. Monfort, B. Sturbois, P. Puigdomènech, M. Pitrat, M. Caboche, C. Dogimont, J. GarciaMas, M.A. Aranda, and A. Bendahmane. 2006. An eIF4E allele confers resistance to an uncapped and non-polyadenylated RNA virus in melon. The Plant Journal 48: 452-462.

Nieto, C., F. Piron, M. Dalmais, C. Marco, E. Moriones, M.L. GomezGuillamon, V. Truniger, P. Gomez, J. Garcia-Mas, M. Aranda, and A. Bendahmane. 2007. EcoTILLING for the identification of allelic variants of melon $e I F 4 E$, a factor that controls virus susceptibility. BMC Plant Biology 7: 34.

Nowara, D., A. Gay, C. Lacomme, J. Shaw, C. Ridout, D. Douchkov, G. Hensel, J. Kumlehn, and P. Schweizer. 2010. HIGS: host-induced gene silencing in the obligate biotrophic fungal pathogen Blumeria graminis. Plant Cell 22: 3130-3141.

NPC. 2014. National Potato Council. 2014 Potato Statistical Yearbook.

OECD. 1997. Organization for economic co-operation and development. Consensus document on the biology of Solanum tuberosum subsp. tuberosum (potato).

Office of Environmental Health Hazard Assessment. 2015. Acrylamide Workplan.

Office of Science and Technology Policy. 1986. Coordinated framework for regulation of biotechnology. Office of Science and Technology Policy 51 FR 23302

Paal, J., H. Henselewski, J. Muth, K. Meksem, C.M. Menendez, F. Salamini, A. Ballvora, and C. Gebhardt. 2004. Molecular cloning of the potato Grol-4 gene conferring resistance to pathotype Rol of the root cyst nematode Globodera rostochiensis, based on a candidate gene approach. The Plant Journal 38: 285-297.

Pandey, P., M. Senthil-Kumar, and K. Mysore. 2015. Advances in plant gene silencing methods. In Plant gene silencing, ed. K.S. Mysore and M. Senthil-Kumar, 3-23. New York: Springer.

Panwar, V., B. McCallum, and G. Bakkeren. 2013. Host-induced gene silencing of wheat leaf rust fungus Puccinia triticina pathogenicity 
genes mediated by the Barley stripe mosaic virus. Plant Molecular Biology 81: 595-608.

Papp, I., L. Mur, A. Dalmadi, S. Dulai, and C. Koncz. 2004. A mutation in the cap binding protein 20 gene confers drought tolerance to Arabidopsis. Plant Molecular Biology 55: 679-686.

Patterson, P. 2013. Cost and returns estimate: Eastern Idaho russet burbank potatoes. EBB4-Po6-13. Moscow: University of Idaho.

Pel, M.A., S.J. Foster, T.-H. Park, H. Rietman, G. van Arkel, J.D.G. Jones, H.J. Van Eck, E. Jacobsen, R.G.F. Visser, and E.A.G. Van der Vossen. 2009. Mapping and cloning of late blight resistance genes from Solanum venturii using an interspecific candidate gene approach. Molecular Plant-Microbe Interactions 22: 601-615.

Perlak, F.J., T.B. Stone, Y.M. Muskopf, L.J. Petersen, G.B. Parker, S.A. McPherson, J. Wyman, S. Love, G. Reed, D. Biever, et al. 1993. Genetically improved potatoes: protection from damage by Colorado potato beetles. Plant Molecular Biology 22: 313-321.

Petersson, E.V., U. Arif, V. Schulzova, V. Krtkova, J. Hajslova, J. Meijer, H.C. Andersson, L. Jonsson, and F. Sitbon. 2013. Glycoalkaloid and calystegine levels in table potato cultivars subjected to wounding, light, and heat treatments. Journal of Agricultural and Food Chemistry 61: 5893-5902.

Phillips, P., and D. Corkindale. 2002. Marketing GM foods: the way forward. AgBioforum 5: 113-121.

Phipps, R., and J. Park. 2002. Environmental benefits of genetically modified crops: global and European perspectives on their ability to reduce pesticide use. Journal of Animal and Feed Sciences 11:1-18.

Pieczynski, M., W. Marczewski, J. Hennig, J. Dolata, D. Bielewicz, P. Piontek, A. Wyrzykowska, D. Krusiewicz, D. Strzelczyk-Zyta, D. Konopka-Postupolska, M. Krzeslowska, A. Jarmolowski, and Z. Szweykowska-Kulinska. 2013. Down-regulation of CBP80 gene expression as a strategy to engineer a drought-tolerant potato. Plant Biotechnology Journal 11: 459-469.

Piron, F., M. Nicolai, S. Minoia, E. Piednoir, A. Moretti, A. Salgues, D. Zamir, C. Caranta, and A. Bendahmane. 2010. An induced mutation in tomato eIF4E leads to immunity to two potyviruses. PLOS ONE 5: e11313.

Pliego, C., D. Nowara, G. Bonciani, D.M. Gheorghe, R. Xu, P. Surana, E. Whigham, D. Nettleton, A.J. Bogdanove, R.P. Wise, P. Schweizer, L.V. Bindschedler, and P.D. Spanu. 2013. Host-induced gene silencing in barley powdery mildew reveals a class of ribonuclease-like effectors. Molecular Plant-Microbe Interactions 26: 633-642.

Puchta, H., and F. Fauser. 2014. Synthetic nucleases for genome engineering in plants: prospects for a bright future. Plant Journal 78: 727-741.

Puchta, H., B. Dujon, and B. Hohn. 1996. Two different but related mechanisms are used in plants for the repair of genomic doublestrand breaks by homologous recombination. Proceedings of the National Academy of Sciences of the United States of America 93: 5055-5060.

Rigano, M.M., G. De Guzman, A.M. Walmsley, L. Frusciante, and A. Barone. 2013. Production of pharmaceutical proteins in solanaceae food crops. International Journal of Molecular Sciences 14: 2753 2773 .

Ron, M., and A. Avni. 2004. The receptor for the fungal elicitor ethyleneinducing xylanase is a member of a resistance-like gene family in tomato. The Plant Cell 16: 1604-1615.

Rousu, M., W. Huffman, J. Shogren, and A. Tegene. 2003. Are United States consumers tolerant of genetically modified foods? Review of Agricultural Economics 26: 19-31.

Ruffel, S., M.-H. Dussault, A. Palloix, B. Moury, A. Bendahmane, C. Robaglia, and C. Caranta. 2002. A natural recessive resistance gene against potato virus $\mathrm{Y}$ in pepper corresponds to the eukaryotic initiation factor 4E (eIF4E). The Plant Journal 32: 1067-1075.

Ruffel, S., J.L. Gallois, M.L. Lesage, and C. Caranta. 2005. The recessive potyvirus resistance gene pot-1 is the tomato orthologue of the pepper pvr2-eIF4E gene. Molecular Genetics and Genomics 274: 346-353.

Ruiz-Ferrer, V., and O. Voinnet. 2009. Roles of plant small RNAs in biotic stress responses. Annual Review of Plant Biology 60: 485-510.

Scurrah, M., C. Celis-Gamboa, S. Chumbiauca, A. Salas, and R.F. Visser. 2008. Hybridization between wild and cultivated potato species in the Peruvian Andes and biosafety implications for deployment of GM potatoes. Euphytica 164: 881-892.

Shukla, V.K., Y. Doyon, J.C. Miller, R.C. DeKelver, E.A. Moehle, S.E. Worden, J.C. Mitchell, N.L. Arnold, S. Gopalan, X. Meng, V.M. Choi, J.M. Rock, Y.Y. Wu, G.E. Katibah, G. Zhifang, D. McCaskill, M.A. Simpson, B. Blakeslee, S.A. Greenwalt, H.J. Butler, S.J. Hinkley, L. Zhang, E.J. Rebar, P.D. Gregory, and F.D. Urnov. 2009. Precise genome modification in the crop species Zea mays using zinc-finger nucleases. Nature 459: 437-441.

Simon, W. 2003. The agricultural advantages and consumer acceptance or otherwise of genetically modified crops with particular emphasis on potatoes. Nuffield Reports: Biotechnology Reports. Nuffield Farming Scholarships Trust 28.

Simplot. 2013. Petition for determination of nonregulated status for innate potatoes with low acrylamide potential and reduced black spot bruise: events E12 and E24 (Russet Burbank); F10 and F37 (Ranger Russet); J3, J55, and J78 (Atlantic); G11(G); H37 and H50 (H). J.R. Simplot Company.

Sindhu, A.S., T.R. Maier, M.G. Mitchum, R.S. Hussey, E.L. Davis, and T.J. Baum. 2009. Effective and specific in planta RNAi in cyst nematodes: expression interference of four parasitism genes reduces parasitic success. Journal of Experimental Botany 60: 315-324.

Smith, D.B., J.G. Roddick, and J.L. Jones. 1996. Potato glycoalkaloids: some unanswered questions. Trends in Food Science \& Technology 7: 126-131.

Song, J., J.M. Bradeen, S.K. Naess, J.A. Raasch, S.M. Wielgus, G.T. Haberlach, J. Liu, H. Kuang, S. Austin-Phillips, C.R. Buell, J.P. Helgeson, and J. Jiang. 2003. Gene RB cloned from Solanum bulbocastanum confers broad spectrum resistance to potato late blight. Proceedings of the National Academy of Sciences of the United States of America 100: 9128-9133.

Sparks, W., and L. Summers. 1974. Potato weight losses, quality changes, and cost relationships during storage. AES Bulletin 535. Moscow: University of Idaho.

Stein, N., D. Perovic, J. Kumlehn, B. Pellio, S. Stracke, S. Streng, F. Ordon, and A. Graner. 2005. The eukaryotic translation initiation factor 4E confers multiallelic recessive Bymovirus resistance in Hordeum vulgare (L.). The Plant Journal 42: 912-922.

Stevens, L.H., and E. Davelaar. 1997. Biochemical potential of potato tubers to synthesize blackspot pigments in relation to their actual blackspot susceptibility. Journal of Agricultural and Food Chemistry 45: 4221-4226.

Tinoco, M.L., B.B. Dias, R.C. Dall'Astta, J.A. Pamphile, and F.J. Aragao. 2010. In vivo trans-specific gene silencing in fungal cells by in planta expression of a double-stranded RNA. BMC Biology 8: 27.

Toevs, E., J. Guenthner, A. Johnson, C. McIntosh, and M. Thornton. 2011a. Identity preservation systems for genetically modified potatoes. American Journal of Potato Research 88: 303-308.

Toevs, E., J. Guenthner, A. Johnson, C. McIntosh, and M. Thornton. $2011 \mathrm{~b}$. An industry perspective of all-native and transgenic potatoes. AgBioforum 14: 14-19.

Tomilov, A.A., N.B. Tomilova, T. Wroblewski, R. Michelmore, and J.I. Yoder. 2008. Trans-specific gene silencing between host and parasitic plants. Plant Journal 56: 389-397.

Townsend, J.A., D.A. Wright, R.J. Winfrey, F. Fu, M.L. Maeder, J.K. Joung, and D.F. Voytas. 2009. High-frequency modification of plant genes using engineered zinc-finger nucleases. Nature 459: 442-445.

Tynan, J., M. Williams, and A. Conner. 1990. Low frequency of pollen dispersal from a field trial of transgenic potatoes. Journal of Genetics and Breeding 44: 303-306. 
USDA Nutrient Data Laboratory. 2015. National nutrient database for standard reference release 27. http://ndb.nal.usda.gov. Accessed 15 May 2015.

USDA-APHIS. 2015. Petitions for determination of nonregulated status. http://www.aphis.usda.gov/biotechnology/petitions_table pending.shtml. Accessed 31 August 2015.

van der Vossen, E., A. Sikkema, B. Hekkert, J. Gros, P. Stevens, M. Muskens, D. Wouters, A. Pereira, W. Stiekema, and S. Allefs. 2003. An ancient $R$ gene from the wild potato species Solanum bulbocastanum confers broad-spectrum resistance to Phytophthora infestans in cultivated potato and tomato. Plant Journal 36: 867-882.

van der Vossen, E.A., J. Gros, A. Sikkema, M. Muskens, D. Wouters, P. Wolters, A. Pereira, and S. Allefs. 2005. The Rpi-blb2 gene from Solanum bulbocastanum is an $\mathrm{Mi}-1$ gene homolog conferring broadspectrum late blight resistance in potato. Plant Journal 44: 208-222.

Van Eck, J., B. Conlin, D.F. Garvin, H. Mason, D.A. Navarre, and C.R. Brown. 2007. Enhancing beta-carotene content in potato by RNAimediated silencing of the beta-carotene hydroxylase gene. American Journal of Potato Research 84: 331-342.

VanWechel, T., C. Wachenheim, E. Schuck, and D. Lambert. 2003. Consumer valuation of genetically modified foods and the effect of information bias. Agribusiness and Applied Economics Report No. 513. North Dakota State University.

Vega-Arreguin, J.C., A. Jalloh, J.I. Bos, and P. Moffett. 2014. Recognition of an $A v r 3 a$ homologue plays a major role in mediating nonhost resistance to Phytophthora capsici in Nicotiana species. Molecular Plant-Microbe Interactions 27: 770-780.

Visser, R.G., I. Somhorst, G.J. Kuipers, N.J. Ruys, W.J. Feenstra, and E. Jacobsen. 1991. Inhibition of the expression of the gene for granulebound starch synthase in potato by antisense constructs. Molecular and General Genetics 225: 289-296.

Vleeshouwers, V.G., H. Rietman, P. Krenek, N. Champouret, C. Young, S.K. Oh, M. Wang, K. Bouwmeester, B. Vosman, R.G. Visser, E. Jacobsen, F. Govers, S. Kamoun, and E.A. Van der Vossen. 2008. Effector genomics accelerates discovery and functional profiling of potato disease resistance and Phytophthora infestans avirulence genes. PLOS ONE 3: e2875.

Vossen, J., S. Dezhsetan, D. Esselink, M. Arens, M. Sanz, W. Verweij, E. Verzaux, and C. van der Linden. 2013. Novel applications of motifdirected profiling to identify disease resistance genes in plants. Plant Methods 9: 37.

Waltz, E. 2012. Tiptoeing around transgenics. Nature Biotechnology 30: $215-217$

Weisz, R., J. Kaminski, and Z. Smilowitz. 1994. Water deficit effects on potato leaf growth and transpiration: utilizing fraction extractable soil water for comparison with other crops. American Potato Journal 71: 829-840.
West, G., C. Gendron, B. Larue, and R. Lambert. 2002. Consumers' valuation of functional properties of foods: results from a Canadawide survey. Canadian Journal of Agricultural Economics 50: 541588.

Wright, D.A., J.A. Townsend, R.J. Winfrey Jr., P.A. Irwin, J. Rajagopal, P.M. Lonosky, B.D. Hall, M.D. Jondle, and D.F. Voytas. 2005. High-frequency homologous recombination in plants mediated by zinc-finger nucleases. Plant Journal 44: 693-705.

Xie, F., T.P. Frazier, and B. Zhang. 2011. Identification, characterization and expression analysis of microRNAs and their targets in the potato (Solanum tuberosum). Gene 473: 8-22.

Yadav, B.C., K. Veluthambi, and K. Subramaniam. 2006. Host-generated double stranded RNA induces RNAi in plant-parasitic nematodes and protects the host from infection. Molecular and Biochemical Parasitology 148: 219-222.

Yang, W., X. Liu, J. Zhang, J. Feng, C. Li, and J. Chen. 2010. Prediction and validation of conservative microRNAs of Solanum tuberosum L. Molecular Biology Reports 37: 3081-3087.

Ye, J., R. Shakya, P. Shrestha, and C.M. Rommens. 2010. Tuber-specific silencing of the acid invertase gene substantially lowers the acrylamide-forming potential of potato. Journal of Agricultural and Food Chemistry 58: 12162-12167.

Yin, C., J.E. Jurgenson, and S.H. Hulbert. 2011. Development of a hostinduced RNAi system in the wheat stripe rust fungus Puccinia striiformis f. sp. tritici. Molecular Plant-Microbe Interactions 24: 554-561.

Yoshii, M., M. Nishikiori, K. Tomita, N. Yoshioka, R. Kozuka, S. Naito, and M. Ishikawa. 2004. The Arabidopsis cucumovirus multiplication 1 and 2 loci encode translation initiation factors $4 \mathrm{E}$ and $4 \mathrm{G}$. Journal of Virology 78: 6102-6111.

Yuan, B.-Z., S. Nishiyama, and Y. Kang. 2003. Effects of different irrigation regimes on the growth and yield of drip-irrigated potato. Agricultural Water Management 63: 153-167.

Zhang, B., X. Pan, Q. Wang, G.P. Cobb, and T.A. Anderson. 2006. Computational identification of microRNAs and their targets. Computational Biology and Chemistry 30: 395-407.

Zhang, W., Y. Luo, X. Gong, W. Zeng, and S. Li. 2009. Computational identification of 48 potato microRNAs and their targets. Computational Biology and Chemistry 33: 84-93.

Zhang, H., J. Guo, R.T. Voegele, J. Zhang, Y. Duan, H. Luo, and Z. Kang. 2012. Functional characterization of calcineurin homologs PsCNA1/ PSCNB1 in Puccinia striiformis f. sp. tritici using a host-induced RNAi system. PLoS ONE 7: e49262.

Zhang, R., D. Marshall, G.J. Bryan, and C. Hornyik. 2013. Identification and characterization of miRNA transcriptome in potato by highthroughput sequencing. PLOS ONE 8, e57233.

Zipfel, C. 2014. Plant pattern-recognition receptors. Trends in Immunology 35: 345-351. 